\title{
Are investors aware of ownership connections?
}

\author{
Edith Ginglinger Camille Hebert Luc Renneboog*
}

\begin{abstract}
We examine the market reactions to earnings announcements by listed firms connected through ownership links. We find that the parents' investors react to all announcements within the group either immediately or with delay, whereas subsidiaries' investors only react to their own firm's announcements, ignoring predictive information released at the parent level. Our findings suggest that multiple announcements within a group lead to enhanced transparency for parents' investors, who benefit from detailed information on the origin of their firm's earnings. In contrast, subsidiaries' investors appear unaware of ownership links, and behave as inattentive investors.
\end{abstract}

JEL Classification: G14, G32

Keywords: Ownership structures, corporate complexity, inattention, unawareness, earnings announcements, business groups, conglomerates, inattention, post-earnings announcement drift, market frictions.

\footnotetext{
* Edith Ginglinger is at Université Paris-Dauphine (Place du Maréchal de Lattre de Tassigny, 75775 PARIS Cedex 16, France) Email: edith.ginglinger@dauphine.fr; Camille Hebert is at Université Paris-Dauphine and Tilburg University Email: camille.hebert@dauphine.fr); and Luc Renneboog is at Tilburg University (POBox 90153, 5000 LE Tilburg, the Netherlands) Email: Luc.Renneboog@uvt.nl. The authors thank Paul Beaumont, Fabio Braggion, Gilles Chemla, Olivier Dessaint, Bart Dierynck, Joost Driessen, Pascal Dumontier, Zsuzsanna Fluck, Alberto Manconi, Roni Michaely, Mario Milone, Ekatarina Neretina, Manju Puri, Emanuele Rizzo, David Robinson, Oliver Spalt, Cara Vansteenkiste and Marius Zoican for valuable comments and helpful discussions as well as the participants to seminars at Tilburg University and Université Paris-Dauphine. The second author is grateful to Duke University for its hospitality during a research visit. All remaining errors and omissions are our own.
} 


\section{Are investors aware of ownership connections?}

\section{Introduction}

Corporate networks, which we define as a group of legally independent firms connected by ownership links and under control of a common owner represent a form of firm complexity that has grown over time in order to take advantage of investment opportunities, meet diversification needs, or make legal or financial constraints less binding. These corporate structures are largely prevalent in Asia (Claessens, Djankov, and Lang, 2000), continental Europe (Faccio and Lang, 2002), but also exist in the U.S. (see for example Holderness (2009) who discredits the myth of diffuse ownership in the U.S.). Information disclosure by one firm within the network can be directly relevant for affiliated firms as equity stakes represent channels through which earnings float. In this paper, we examine how shareholders respond to information releases by the various entities of the corporate network and investigate whether these structures lead to enhanced transparency as investors receive more detailed information coming from different entities or to more opacity when investors are unable to comprehend the connections between the announcing firms.

When corporate networks consist of firms located in different countries, operating in different industries, or whose corporate names do not reveal any connection, it may be harder for investors to comprehend that these entities are all part of the same corporate network and to process information released by the various members of the group. This would be especially the case when information is disclosed by group members in which the investors do not hold a direct ownership stake. In contrast, smart investors may be able to update their views more frequently on the firm they invest in.

To examine information flows within corporate networks, we identify parent-subsidiary ownership structures where both parent and subsidiary are publicly listed and their sets of shareholders only partially overlap. Throughout the paper, we will use the term subsidiaries for firms in which a parent owns at least a $20 \%$ stake and are hence presumably consolidated (following IFRS standards). The parent can hold a direct stake in the subsidiary or exert control by means of a string of intermediate firms. Thus, a parent company's stock can be regarded as a weighted portfolio of listed and unlisted corporate entities, where the weights are determined by ownership stakes in subsidiaries and the subsidiaries' relative sizes. At least once a year, the listed parent and subsidiary companies are required to make a public and separate announcement of their earnings. By studying the market reactions to the release of unanticipated earnings information, we can identify whether investors are able to see through the complexity of the group structure or whether corporate complexity induces investor unawareness. Indeed, the fact that a related listed parent and subsidiary have to a large extent a distinct set of investors, and that both firms release separate earnings information - possibly at different dates - enables us to examine how the investors of both types of firms react to the information disclosure of these affiliated firms. We first confirm that there is relevant information for the shareholders of 
the subsidiary (parent) in the earnings announcement of the parent (subsidiary). We regress the earnings surprise of a given firm on that of the connected firm and find a positive link between both announcements, which confirms there is useful information in the earnings announcements of the connected firms. We then distinguish among three cases based on the timing of earnings information release: (i) the parent and subsidiary announce on the same day, (ii) the parent announces first, and (iii) the subsidiary announces first. Market efficiency predicts that investors fully and immediately incorporate the earnings surprise information unanticipated by the market, the anticipated part of the information (expected or forecast earnings) being already priced.

When the earnings announcements do not coincide, we conjecture that the first company to announce unanticipated information also conveys predictive information about the affiliated company (the second announcer). Consequently, unanticipated information released by the first announcer should not only trigger an immediate share price reaction for the first announcer but also for the second one. Specifically, the first announcer's surprise earnings announcement is particularly informative when the equity stake of the parent in the subsidiary is larger, when the investment from the parent into the subsidiary is direct (i.e. in contrast to using several intermediate investment vehicles), and when the subsidiary represents a large part of parent company's assets. The enhanced transparency conjecture states that investors are expected to perceive the ownership links, entailing that the surprise earnings of all announcing companies belonging to the network increase the amount of information available to investors. This additional source of information should be immediately and fully incorporated in the share prices of all listed firms in the group.

The alternative conjecture is that investors are unaware of the ownership links and do not react, neither immediately nor with delay to the earnings announcements of the affiliated company, and have hence a blind spot with regard to the corporate network. A variation of this conjecture is that investors are myopic: they are aware of the ownership links, but complexity induces delays in processing information released by affiliated companies. We consider the delayed stock price reaction to earnings surprises, measured by the post-earnings announcement drift (PEAD) as an indication of investor inattention (Bernard and Thomas 1989, 1990; DellaVigna and Pollet 2009; Hirshleifer, Lim, and Teoh 2009).

Our analysis is based on a sample of 15,169 ownership link-year observations, corresponding to 2390 unique (direct or indirect) parent-subsidiary links in 75 countries over the period 2000-2015. First, we find that when the parent and the subsidiary release earnings surprises on the same day, investors of both firms strongly react to the announcements without delay. However, these pooled announcements do not enable us to identify the information source to which each group of investors reacts. Second, when the parent company releases its earnings prior to that of the subsidiary, we find that parent's investors react both to their own surprise earnings announcement and to the subsidiary's announcement that takes place at a subsequent point in time. This implies that the parent's investors infer that the subsidiary's announcement contains 
additional information that was not priced yet at the parent's initial announcement of the aggregated information of the whole group and supports the enhanced transparency conjecture. In contrast to a parent company's investors, the subsidiary's investors only react to the subsidiary's announcement, ignoring the exante and hence predictive information released at the parent level. This suggests that the subsidiary's investors are unaware of the ownership relation between subsidiary and parent and fail to see how their firm is embedded in a corporate network. Third, when the subsidiary announces its earnings surprise first, we observe that both the subsidiary's and parent's investors immediately incorporate this information in the share prices, but do so only partially as the share prices keep adjusting in the period after the subsidiary's announcement to fully incorporate the news (reflected in the PEAD).

We explore three potential explanations of our findings. First, investors may have a blind spot in the sense that they do not perceive that companies are intertwined within a complex ownership web. Hence, investors do not react to the announcements of an affiliated company as they fail to observe the internal structure of the corporate group. The theoretical argument is based on Merton's (1987) model in which the investors are not aware of the entire universe of securities and obtain information on a small number of stocks, leading to the phenomenon of neglected stocks. In our setting, this would mean that investors do not perceive the group as a whole, and mainly consider the firm in which they have invested directly. When the parent announces first, Merton's argument applies to a subsidiary's investors who react to their own firm announcements, but not to the parent's. A possible explanation for the lack of share price reaction to the announcement of earnings surprises could be that a subsidiary may not be that important for the parent and the parent's earnings surprise may be generated by other subsidiaries. Still, the average ownership link of $46 \%$ and the average subsidiary making up $41 \%$ of the parent's market value implies that the parent's investors claim on average $19 \%$ of the cash flow rights of the subsidiary. Consequently, information released by a parent is economically relevant for a subsidiary's investors, which combined with the lack of or delayed share price reaction supports our conjecture about the subsidiary investor unawareness towards the ownership links.

Second, when the parent announces first, the parent's investors immediately react to this announcement and also immediately react when the subsidiary announces an earnings surprise subsequently time. This result implies that the group structure enhances the quantity of information available to the parent's investors. They initially receive information on the aggregate earnings of the parent company, and subsequently - when the subsidiary announces its own earnings - also on the composition of the parent's aggregate earnings (namely on the degree to which a listed subsidiary contributes to the value creation in the group). These findings support the enhanced transparency conjecture.

Third, when the subsidiary announces first, we find that parent's and subsidiary's investors are inattentive to the announcements: they react with delay to both earning announcements. The immediate reaction to their own announcements accounts for 50-66\% of the total reaction over the period up to 60 
days $^{2}$, whereas the immediate reaction to the other firm's announcements merely represents 0 to $15 \%$ of the total reaction. When the subsidiary announces first, not all parent's investors seem to be aware of the ownership or they are inattentive as information processing takes more time. Furthermore, even if they were aware of the connections, investors may have difficulty interpreting information in a context of network complexity, which may also explain the delayed reaction to both their own and the affiliated firm's earning announcements.

Then, we investigate possible explanations of investors' inattention to connected firms' announcements. Unawareness may be correlated to the degree of ownership complexity that may require more sophisticated analysis by investors. Besides, there are several reasons why subsidiary's investors may be more susceptible to inattention. Investors are more likely to obtain a broad picture of a complex group when they invest in the head of the group rather than in an entity within the corporate network. When holding equity in the parent, investors seek what drives value, or in other words, which subsidiaries contribute most to value. Furthermore, from the point of view of a listed subsidiary's outside investors, the parent company's news, even if it is disclosed first, may be less informative because other subsidiaries' performance may blur that of the listed subsidiary. Hence, understanding how the consolidated news relates to the individual entities of the group may require sophisticated analysis. Moreover, smaller subsidiaries are less liquid because of more concentrated ownership and the presence of fewer institutional investors. If a majority of the shareholders of the subsidiary are non-sophisticated investors, the reaction to announcements, especially for complicated firms, may be understandably delayed. We find that investors are less myopic when a subsidiary is located in the same country and is directly owned. Still, information is not more readily incorporated into share prices when the parent and subsidiary share part of a corporate name, and when the subsidiary contributes to greater extent to the parent's value (a higher ownership stake of the parent in the subsidiary combined with a larger relative size of the subsidiary). The presence of institutional investors and of common institutional investors holding equity in both parent and subsidiary does not affect our results.

We conduct several tests to address endogeneity issues and alternative explanations: First, it could be that the decision to announce first or jointly may be endogeneous in that if the management of the parent and/or subsidiary anticipate different share price reactions that depend on the timing of the announcement, they may try to steer the share price reactions by announcement timing. In the specific case of listed parentsubsidiary structures, financial communication calendars may be (de)synchronized depending on the quality or type of the news announcement, i.e. a negative or positive earnings surprise (e.g. Begley and Fischer, 1998; Bagnoli, Kross, and Watts, 2002; Doyle and Magilke, 2009). We verify whether the announcement timing is related to the type of earning surprise and/or to characteristics of the subsidiary and the parent. We find some evidence of strategic timing of the information disclosure by parent and subsidiary, but the results

\footnotetext{
${ }^{2}$ Given that the second announcer's information can fall within this window, our conclusions are also based on uncontaminated windows, as will be discussed below.
} 
on investor reactions do not depend on the timing of who releases earnings surprise information first and on whether the earnings surprise is positive or negative. Therefore, we confirm that our findings are sustained after controlling for these issues.

Second, when the subsidiary announces first, we interpret the delayed market reaction as resulting from investor unawareness. This finding may not just result from complexity induced by ownership-links but from releasing information on days when inattention is usually high. The traditional inattention literature examines investor distraction with regard to information timing of stand-alone firms such as the effect of information announcements on Friday (DellaVigna and Pollet, 2009), busy days (Hirshleifer, Lim and Teoh, 2009), and busy hours (Michaely, Rubin and Vedrashko, 2014). In all our models, we control for year, month, and day of the week fixed-effects.

Third, absence of or delayed investor reaction that we interpret as investor unawareness, may be driven by illiquid stocks (i.e. many subsidiaries may have a lower free float given the presence of a major shareholder, the parent). In all our models, we include a measure of stock illiquidity, which makes it more unlikely that illiquidity effects are the main drivers of our findings.

Fourth, while we interpret the absence of a subsidiary's investor reaction to the surprise earnings announcement by the parent who announces first as the result of unawareness of the ownership link, an alternative explanation could be that the subsidiary's investors fear rent extraction from the subsidiary by the parent (tunneling) (Johnson, La Porta, Lopez-de-Silanes, and Shleifer 2000; Dyck and Zingales, 2004; Atanasov, Boone and Haushalter, 2010). We conduct several tests on potential tunneling but do not find evidence that our findings are affected by expropriation of subsidiary earnings by the parent firm.

Fifth, a related idea is that internal capital markets may exist that permit corporate groups to allocate capital from firms with excess funds to entities that have profitable projects that they are unable to finance with internally generated funds (Maksimovic and Phillips (2013) provide an overview of this literature). We find that, when a parent announcing first has negative earnings, its investors react more favorably to the subsequently announced positive earnings surprise from the subsidiary, and this effect is amplified when the parent's growth opportunities are larger than the subsidiary's. These findings suggest that investors may value the existence of internal capital markets. These results hold only in the case of parent announcing first and for the parent's investors, and reconfirms the enhanced transparency conjecture for this case.

Sixth, we test the robustness of all our findings to any consideration related to the endogeneous formation of the corporate networks (e.g. vertical integration, diversification). We include pair parentsubsidiary industry (country) fixed effects to account for unobserved complementarities and synergies between parent companies and subsidiaries operating in different industries (countries), and we confirm these effects do not affect the way investors react to information released by their company or by the affiliated entity. 
Our paper is related to several strands of literature. First, we add new evidence on the flow and interpretation of information within 'complicated firms'. ${ }^{3}$ Cohen and Lou (2012) compare standalone and conglomerate firms subject to the same information shock. They find that investors' limited processing capacity leads to a significant delay in impounding information into share prices of conglomerate firms, generating return predictability. Huang (2015) finds that foreign operations' information of multinational firms is only slowly incorporated into stock prices. We document that investors' processing capacity depends on earnings announcement timing by parent or subsidiary and that, overall, the parent's investors are better at processing information than the subsidiary's. Previous literature has identified settings where withinconglomerate information sharing can generate value: for instance, Massa and Rehman (2008) find that mutual funds operated by financial conglomerates have superior performance, arguably because information is shared by their banking division. Anjos and Fracassi (2015) argue that conglomerate firms have an informational advantage relative to specialized firms, because they have better access to business-relevant information and can therefore generate more value compared to stand-alone firms. Our setting of ownership networks suggests that firms within this network generate information that yields higher transparency that could be beneficial for all the investors in the various entities of the group, but is only picked up by some types of investors.

Second, we contribute to the literature on inattention to information from connected firms (whereby connections are based on industry-relatedness, customer-supplier relations and strategic alliances). Ramnath (2002) investigates the reaction of investors of non-announcing firms to the earnings reports of the first announcer (a rival) within an industry. He finds that, despite the fact that the first industry announcement is informative for the subsequent announcers, investors underreact to this type of news. Cohen and Frazzini (2008) show that stock prices do not fully incorporate news related to a firm's principal customers. Cao, Chordia, and Lin (2016) examine the impact of information released by one partner in a strategic alliance on the share price of the other partner. They document a share price underreaction to information release by the other partners regardless of whether the information is positive or negative. Barinov, Park and Yildizhan (2016) find that the PEAD is stronger for conglomerates than for single-segment firms. Massa and Zaldokas (2016) explore how negative credit event information spreads among unrelated but co-owned firms. They conclude that a firm's value is sensitive to cash flow shocks in and financial conditions of co-owned firms, which provides a signal about the monitoring ability of the blockholder. As these papers examine firms related through different types of external links but do no analyze corporate relations within ownership networks, our paper tries to fill this gap by providing evidence of investor inattention (largely on the part of subsidiary's investors) and the benefits of corporate networks such as enhanced transparency (largely on the part of parent's investors).

\footnotetext{
${ }^{3}$ Several papers examine valuation issues of complex firms, see for example Slovin and Sushka (1997), Lamont and Thaler (2003) and Laeven and Levine (2008).
} 
Third, our paper contributes to the business group literature. Firms belonging to corporate networks must report their financial information separately, as opposed to segment-level data in the U.S. for instance (e.g. Berger and Ofek (1995), Lamont (1997), and Shin and Stulz (1998). Gopalan et al. (2007) study intragroup loans in Indian business groups. Almeida, Park, Subrahmanyam, and Wolfenzon (2011) and Almeida, Kim and Kim (2015), respectively, try to empirically understand the endogeneous formation of cross-firm equity investments in Korean Chaebols. While these studies rely on country-specific samples to observe performance and value effects, other papers concentrate on regional samples in order to compare institutional characteristics and explain differences in ownership structures (Claessens et al. (2000) for Asia; Faccio and Lang (2002) for Europe). Beuselinck et al. (2014) analyze earnings management within multinational corporations. Finally, Belenzon et al. (2017) study the autonomy of distant subsidiaries from the headquarters in the corporate network. Our findings contribute to the understanding of how investors perceive earnings announcements made by companies belonging to a network based on ownership links.

Fourth, our paper contributes to the literature on strategic timing of information disclosure. An extensive literature has highlighted that managers attempt to strategically time their earnings announcements, by announcing bad news on Friday (Penman, 1987, DellaVigna and Pollet, 2009, Michaely, Rubin and Vedrashko, 2016), after the market closes (Doyle and Magilke, 2009), by advancing their announcement relative to the initial schedule in case of good news and delaying it in case of bad news (Johnson and So, 2017), or by changing the advance notice period of the date of earnings announcements in case of bad news (Boulland and Dessaint, 2017). These studies examine independent firms. Within corporate networks, we find some evidence of strategic timing of disclosure, but it does not affect investor responses to surprise earnings announcements.

The remainder of the paper is organized as follows. In Section 2, we describe the sample selection and give descriptive statistics of the main variables. We report our results in Section 3 and the results from a set of robustness tests in Section 4. Section 5 concludes.

\section{Sample Selection}

\subsection{Ownership Links}

We start our data collection by retrieving shareholder information for all (currently and formerly) listed companies around the world from Bureau van Dijk's Orbis database. We find 360,000 ownership links between a public company and a public (downstream) company. ${ }^{4}$ Still, most of these ownership links are participation stakes held by financial institutions including insurance companies (45\% of all of the above links) or mutual funds (25\%) and these equity stakes are small with an average (median) of $4.52 \%(0.56 \%)$ of the equity. Some of the equity stakes in Orbis are not given in a numerical format, which is why we

\footnotetext{
${ }^{4}$ Bureau van Dijk's Orbis database provides owner and subsidiary links for more than 40 million public and private companies. The data are collected from different data sources including the SEC Edgar files for US listed companies, firms' annual reports, firms' websites, and direct solicitations. Orbis relies on a network of 77 local data providers to collect international ownership data.
} 
decode them following Kalemli-Ozcan et al. (2015): we replace a percentage with a leading "<", or "> " by the percentage after the symbol plus or minus $0.1 \%$; we eliminate possible signs that preceded percentages: “_", "?", or "Â"; the "WO" codes (wholly owned) are replaced by 98.01\%; "MO" (majority owned) by $50.01 \%$ (because according to the international accounting standards practice, majority ownership is at least $50 \%$ plus one share and the smallest stake reported by BvD is at two decimals, $0.01 \%$ ); "CQP1" (50\% plus 1 share) by 50.01\%; "BR" (branch) by 50.01\%; "JO" (jointly owned) by 50\%; "NG” (negligible) by $0.01 \%$; and "n.a” (not available) and "-“ (not significant) by zero.

Our aim is to identify investor reactions to a credible signal emitted by a related company, i.e. a subsidiary that directly or indirectly significantly contributes to the parent's earnings. La Porta et al. (2000) define a large owner as a legal entity that directly or indirectly controls at least $10 \%$ of the voting rights. Claessens et al. (2000) use a 20\% cutoff to study concentrated ownership structures and claim that with this percentage a public firm is likely to be fully controlled by a unique ultimate owner. We follow the literature and retain the ownership links with a percentage equal to or above $20 \%$. Since 2005 , there has been a strong push for harmonization of accounting standards and principles with the mandatory adoption of International Financial Reporting Standards (IFRS) for publicly traded firms, which largely coincides with U.S. GAAP. Both U.S. GAAP and IFRS require parent companies to consolidate controlled subsidiaries. IFRS standards require the parent to consolidate the entity if there is de facto control, which is interpreted as the parent owning a stake of $20 \%$ or more (see Appendix B).

Our 2016 cross-sectional sample of ownership links comprises 14,572 subsidiary-parent relations involving 20,616 listed companies. We drop the (4,537) links where ISIN codes are missing. We expand the sample going back 16 more years (2000-2015) and obtain a panel of 54,917 link-year observations based on ownership links of publicly listed parent companies that ${ }^{5}$ effectively directly or indirectly control at least $20 \%$ percentage of the equity of publicly listed subsidiaries. ${ }^{6}$

\subsection{Earnings Surprises}

We collect earnings announcement dates, realized earnings per share, and analysts' earnings forecasts, as provided by the I/B/E/S U.S. and International files. We follow the accounting and finance literature by defining earnings surprises as the difference between the announced earnings and the analysts' forecasts from the period prior to the announcement. Following DellaVigna and Pollet (2009), we take each analyst's most recent forecast prior to the announcement provided that the forecast is not older than 180 days prior to the announcement and not more recent than 3 days before the announcement (to avoid recent forecasts being affected by leakage of information on realized earnings), thereby limiting the sample to one

\footnotetext{
${ }^{5}$ We link the Orbis ownership information to Datastream and I/B/E/S databases using the ISIN identifier.

${ }^{6}$ We correct the data for potential mistakes; e.g. we deleted the link-year observations prior to the IPO year, and after the delisting and full takeover year. IPO and delisting dates are collected from BvD Amadeus and Datastream. Takeovers dates are collected from BvD Zephyr as it has common identifiers with the Orbis database. We also retrieved all historical ownership links available in the Orbis Historical files related to companies involved in the sample of cross sectional links.
} 
forecast per analyst. Our earnings forecast is the median of all analysts' forecasts. We scale the difference between the realized earnings and the median analyst forecast by the share price taken five trading days prior to the announcement. Thus, our estimate of the earnings surprise for firm $i$ on day $\tau$ can be written as:

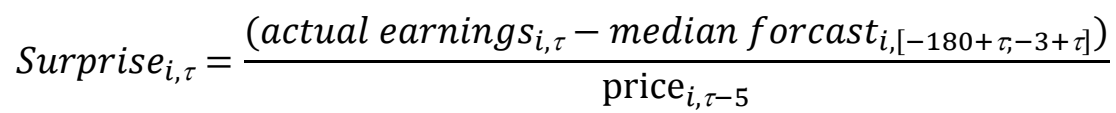

The variable Top Two Quantiles $\tau_{i}$, which is the independent variable of interest, is defined following DellaVigna and Pollet (2009):

$$
\text { Top Two Quantiles }_{\tau_{i}}= \begin{cases}1, & \text { Surprise }_{i, \tau} \in\{Q 10 ; Q 11\} \\ 0, & \text { Surprise }_{i, \tau} \in\{Q 1 ; Q 2\}\end{cases}
$$

The variable Surprise $_{i, \tau}$ distribution is split into 11 quantiles $Q$, with $Q 6$ being the quantile with a

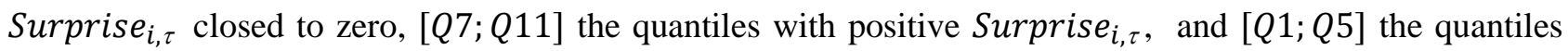
with negative Surprise $e_{i, \tau}$.

As we work with a global sample, we convert all quantities to USD by means of daily exchange rates from Datastream. We delete the observations with extreme earnings surprises (in absolute value is greater than one). We focus on the annual earnings announcement because the practice of quarterly earnings announcements is not universally mandatory, and companies subject to IFRS around the world are required to announce their earnings on an annual basis (Hung, Li, Wang, 2014). ${ }^{7}$ In an international context, most studies find that annual earnings announcement are informative, especially for firms in countries with higher quality earnings and with stronger investor protection institutions (DeFond, Hung, and Trezevant, 2007), and after firms cross-listed in the U.S. (Bailey, Karoly, and Salva, 2006).

\subsection{Investor Reactions}

The stock return at an earnings announcement represents the change in a firm's valuation induced by investors' buying and selling transactions triggered by the difference in earnings relative to expectations. We compute cumulative abnormal returns for different windows at the date $\tau_{i}$ of parent's and subsidiary's earnings announcement for each set of investors - where $i=\{p, s\}, p$ stands for the parent company and $s$ for the subsidiary. We download daily returns from Datastream and denote $r_{i, t}$ as the returns of the share of a company $i$ on day $t$. We calculate cumulative abnormal returns, $B H A R_{i, \tau_{i}}\left[\tau_{i} ; \tau_{i}+T\right]$, over a $\left[\tau_{i} ; \tau_{i}+T\right]$ window as buy-and-hold returns:

$$
\prod_{t=\tau_{i}}^{\tau_{i}+T}\left(1+r_{i, t}\right)-1-\widehat{\beta_{l, t}}\left[\prod_{t=\tau_{i}}^{\tau_{i}+T}\left(1+r_{m, t}\right)-1\right]
$$

\footnotetext{
${ }^{7}$ As of today, 114 countries have converged to IFRS (see Appendix B for more details). In many countries, the usefulness of mandatory reporting of quarterly earnings has been questioned, as they are believed to strengthen a short-term focus at the expense of the long run. E.g. the Interim Management Statements, introduced in 2007 in the UK, were abandoned in 2014. In 2013, the European Commission amended its Transparency Directive stating that quarterly financial information is not necessary for investor protection.
} 
where $r_{m, t}$ is the daily market portfolio return. $\widehat{\beta_{l, t}}$ are obtained by regressing individual returns on the MSCI World 600 index returns for an estimation window $[-300 ;-46]$. We drop the announcements for which we have less than 40 days of stock price data.

For each pair of parent $p$ and subsidiary $s$ in each year $t$ of the sample period, we study two sets of investor reactions at two earnings announcement dates, namely $\tau_{p}$ and $\tau_{s}$, yielding a total of four reactionannouncement observations in a given year.

Our main test is captured by the following equation:

$$
\begin{aligned}
\text { BHAR }_{i, \tau_{i}}\left[\tau_{i} ; \tau_{i}+T\right]=\alpha & +\beta \text { Surprise Top Two Quantiles } \text { Q }_{i} \\
& + \text { S Firm Controls }{ }_{\mathrm{i}, \tau_{i}}+\Theta \text { Link Controls }_{p, s, \tau_{i}}+a_{p, s}+b_{\tau_{i}}+\varepsilon_{i, \tau_{i}}
\end{aligned}
$$

where the vector Firm Controls $i_{i, \tau_{i}}$ comprises the firm characteristics including the log of market capitalization, the log of analyst coverage, the market-to-book ratio, and a dummy equaling one if the company has more than $50 \%$ of zero-return days in a given year. Link Controls $_{p, s, \tau_{i}}$ is a vector of a pair $(p, s)$ characteristics including the companies' relative size, percentage of common analysts, percentage of control held by the parent, a dummy variable indicating a direct ownership relation, and dummy variables equaling one if the parent and subsidiary are located in the same country, and have part of their name in common, respectively. We also include industry and time (year, month, day-of-the-week) fixed effects $\left(b_{\tau_{i}}\right)$, and in some specifications link (parent-subsidiary) industry fixed effects or link fixed effects $\left(a_{p, s}\right)$. The dependent variable $B H A R_{i, \tau_{i}}$ is calculated by type of investor (i.e. $p$ or $s$ ), each of which is expected to respond to the surprise earnings announcements of $p$ or $s$ (at $\tau_{p}$ or $\tau_{s}$ ). This gives four combinations: (1) parents' investor reactions to the parent companies' announcements $\left(B H A R_{p, \tau_{p}}\right),(2)$ subsidiaries' investor reactions to subsidiaries' announcements $\left(B H A R_{S, \tau_{S}}\right)$, (3) parents' investor reactions to subsidiaries' announcements $\left(B H A R_{p, \tau_{s}}\right)$, and (4) subsidiaries' investor reactions to parents' announcements $\left(B H A R_{s, \tau_{p}}\right)$.

\subsection{Description of the Sample}

\section{Geographic breakdown}

The geographical distribution of parents and subsidiaries spans 75 countries. We partition these countries into six categories, in addition to the U.S. and Great Britain. The category 'Asia' includes China, Hong Kong, Korea, Indonesia, Japan, Myanmar, Singapore, Thailand, Philippine, India, Singapore, and Thailand. The category 'Europe' includes Albania, Austria, Belgium, Croatia, Cyprus, Czech Republic, Germany, Denmark, Spain, Finland, France, Ireland, Greece, Hungary, Italy, Lithuania, Luxembourg, The Netherlands, Norway, Poland, Portugal, Romania, Russia, Slovakia, Sweden, Switzerland, and Ukraine. ${ }^{8}$ The

\footnotetext{
${ }^{8}$ By comparaison, Claessens et al. (2000)' sample includes China, Hong Kong, Korea, Indonesia, Japan, Myanmar, Singapore, Thailand, Philippine, and India. Faccio and Lang (2002)' focuses on 15 western continental European countries: Austria, Belgium,
} 
'Americas' comprises Canada, Latin America, and Caribbean islands. The group Middle East includes Israel, Turkey, Lebanon, Oman, and Saudi Arabia. AU/NZ stands for Australia and New Zeeland.

About $72 \%$ of parent companies and subsidiaries are situated in the same geographic region. Fiftyfive percent of the corporate networks around the world are from Asia. Within the Asian groups, 58\% are Japanese, about 10\% are Chinese (including Hong Kong), 13\% are Korean, and the remainder is from India (6\%), Singapore (4\%), Thailand (4\%), Myanmar (4\%) and Indonesia (2\%). Western continental Europe stands for $16 \%$ of all the corporate groups (globally), the U.S. for $11 \%$, the Great Britain for $4 \%$ and the rest of the world for $14 \%$.

\section{[Insert Table 1 about here]}

\section{Descriptive statistics}

Table 2 reports descriptive statistics of the main explanatory and control variables. Means (medians) of various firm characteristics are reported for the subsamples of parents, subsidiaries, and parent/subsidiary pairs (called links). We provide a complete list of variable definitions in the Appendix A and discuss here only the main variables. Subsidiaries are on average followed by eight analysts while parents are followed by almost 14 analysts, which follows from the fact that parents are larger and more visible. The average (median) size of the subsidiary represents $41 \%$ (12\%) of the average (median) parent company.

Parent company's stocks are more liquid than the subsidiaries', which have on average a lower free float. The average parent (subsidiary) has 25 (13) institutional investors, which control 16\% (11\%) of the average parent (subsidiary). Institutional investors are identified using BvD Orbis and include mutual funds, pension funds, hedge funds, venture capital and private equity funds, banks and insurance companies that own between $0.1 \%$ and $20 \%$ of the equity. ${ }^{9}$ Thirty-nine percent of the parents and subsidiaries have at least one common institutional investor. On average, they have five common owners.

The average parent-subsidiary structures are geographically focused ( $72 \%$ of the links are in the same country), diversified (58\% operate in different industries), and 27\% share part of the corporate name. The average ownership stake by the parent in the subsidiary amounts to $48 \%$ and the relative market value of the subsidiary is $41 \%$, such as the average subsidiary represents $19 \%\left(0.48^{*} 0.41\right)$ of the parent's value, which is economically important enough to expect investors to react to the earnings release of the related company. In $21 \%$ of the parent-subsidiary combinations, both companies report SUEs in the two highest SUE quantiles (out of 11 quantiles), and in $19 \%$ of the cases, both report SUEs in the lowest two quantiles (not reported).

\section{[Insert Table 2 about here]}

Germany, Denmark, Spain, Finland, France, Ireland, Greece, Italy, Luxembourg, The Netherlands, Norway, Portugal, Sweden, and Switzerland.

${ }^{9}$ We exclude governments, corporate, and family owners falling under this condition. 


\section{Empirical Results}

In this section, we focus first on parents' and subsidiaries' investor reactions to the earnings announcements of their own firms as well as to those of the affiliated companies. We then examine the effect of relative announcement timing on share prices in order to understand when (if at all) information is incorporated into stock prices.

\subsection{Investor Reactions to Earnings Announcements}

A parent's earnings announcement contains all the earnings of its various operations, including those of its subsidiaries, such that the parent's announcement conveys information on the corporate network, relevant to both the parent's and subsidiaries' investors. Similarly, when a subsidiary announces its earnings first, the market receives predictive information about part of a parent's consolidated future earnings.

In Table 3, we regress investor reactions on announcements of earnings surprises belonging to the top and bottom quantiles of their distribution. The parameter estimate of Surprise Top Two Quantiles measures the returns to good news (top two quantiles) relative to bad news (bottom two quantiles) and we expect the parameter estimate to be positively correlated with the investor reaction.

Our empirical setting with two sets of investors and two earnings events per year enables us to study the investor reaction to the earnings announcement for four combinations of investor reaction-firm announcement. We control for the fact that firms can announce their earnings on the same day or that either the parent or the subsidiary announces first. For each combination, we look at the immediate and the delayed response to the event day which we label day 0 , respectively windows $[0 ; 1]$ and $[2 ; 60]$. For models that test investor reactions to earnings surprises of the company they have invested in, we control for that company's characteristics and industry (SIC-2) fixed effects. For models that test investors reactions to the earnings surprise of the affiliated company, we include (i) characteristics of that affiliated company (firm size, analyst coverage, market-to-book (Q), and stock illiquidity), (ii) link (parent-subsidiary) control variables (such as the parent's ownership percentage in the subsidiary, the percentage of common analysts, the presence of common institutional investors, and the size of subsidiary relative to that of the parent), (iii) link (parent-subsidiary) industry fixed effects that account for unobserved heterogeneity not only related to these firms' own industries but also to combination of industries wherein the parent and its subsidiary operate and (iv) time-independent characteristics of the links (e.g. dummies for a parent and subsidiary being located in the same country, operating in the same industry, or bearing a common name). This specification accounts for the endogeneous formation of business groups, driven by unobserved complementarities, synergies, or inadequacies between industries. We include year, month, and day-of-the week fixed effects, in order to rule out the effects of business cycles, within-year seasonalities, day-of-the-week inattention (e.g. the Friday effect) (Barber et al., 2013). Robust standard errors are reported in all regressions. 
Table 3 presents the results of the share price reactions: Buy-and-hold abnormal returns at the announcement period $[0 ; 1]$ and the subsequent period $[2 ; 60]$ measuring the post-earnings announcement drift (PEAD). We examine whether parent's and subsidiaries' investors react differently to the announcement of their own firm and the affiliated firm. Columns (1) and (2) report the parent's investor reaction to the parent's own announcement. We find a strong, immediate positive reaction of $1.38 \%$, and a PEAD not significantly different from zero. The parent's investor reaction to its subsidiary's surprise earnings announcements are shown in columns (3) and (4): These investors do incorporate the information released by the subsidiary into the share prices, although some of the information is incorporated with delay (at the $10 \%$ level, we find a PEAD of $0.8 \%$ ). Columns (5) and (6) reveal that the subsidiary's investors do react to the subsidiary's earnings announcement and half of the price reaction takes place immediately and the other half up to 60 trading days after the announcement. The PEAD is economically and statistically significant and robust to the subsidiary's controls such as firm size and a firm's stock illiquidity.

In sum, our results support the fact that parent's and subsidiary's investors do not react in the same way to information released by the affiliated company; for instance, in contrast to the parent's investors, subsidiary's investors do not incorporate information on the affiliated firm into their share prices. This violation of the efficient market hypothesis may follow from a lack of investor sophistication (inattention) or alternative explanations that we explore further in the next section where we dig one level deeper and distinguish among three event-timing cases.

\section{[Insert Table 3 about here]}

\subsection{Relative Announcement Timing and Information Incorporation}

We dissect our sample into three timing types, respectively the case where the parent and its subsidiary release their earnings on the same day, where the parent company announces first (before the subsidiary), and where the subsidiary announces first. For most parents and subsidiaries (about 84\%) within a pair, the financial year ends coincide (Table 4). Of these pairs, $16 \%$ announce their annual earnings on the same day. For $47 \%$, the subsidiary's earnings announcement is scheduled before that of the parent; and for $37 \%$, the subsidiary releases its earnings subsequent to the parent. When the subsidiary is the first announcer, the parent announces on average (median) 13 (7) calendar days afterwards. When the parent is the first announcer, the subsidiary's announcement is scheduled 23 days later (with a median of 14 days).

\section{[Insert Table 4 about here]}

For the cases where parent and subsidiary do not announce on the same day, we perform four different tests: we measure the parents' and subsidiaries' investor reactions to the announcements of their own firms, and their reactions to the announcements of the affiliated firms. In each setting, we study investor reaction or inattention, and estimate immediate and delayed reactions to the earnings surprises. 


\subsubsection{Parent and subsidiary announce on the same day}

Table 5 reports the average immediate and delayed reactions of parent's and subsidiary's investors to same-day earnings announcements. Both the parent's and subsidiary's investors instantaneously react to the announcement of their respective companies in models (1) and (5). Consistent with market efficiency, the reaction is immediate and there is no post-earnings announcement drift (Models (3) and (7)). The results remain unchanged when we control for firm characteristics such as stock illiquidity, firm size, analyst coverage, and industry and time (year, month, day-of-the-week) fixed effects (see Models (2), (4), (6) and (8)). As the stock price reactions may also reflect the incorporation of information about the affiliated company given that the announcements coincide, we cannot identify whether the stock price reactions are driven by information released by the parent or the subsidiary or both. Therefore, we turn to the cases where the parent and the subsidiary disclose their earnings at distinct moments in time.

\section{[Insert Table 5 about here]}

\subsubsection{The parent announces first}

\section{Parent's investor reactions}

When the parent releases its earnings before the subsidiary, investors could react twice in case the second announcement (by the subsidiary) also contains new or previously unpriced information. We find that parent's investors strongly react to their own earnings surprises, with a statistically significant BHAR of almost $1 \%$ on the announcement day (Table 6, Panel A, Model 1) and that there is no delayed stock price reaction (Model 3). These results are robust to including firm-industry, parent-subsidiary industry, and time (year, month, day-of-the week) fixed effects.

As a parent's earnings reflect the consolidated earnings from its listed and non-listed subsidiaries, the stock price reaction at the announcement is expected to fully incorporate all relevant information, which is why we would expect no reaction by the parent's investors to the subsidiary's announcement if this follows soon after the parent's announcement. Still, we show that parents' investors do also react to the subsequent release of surprise information by the subsidiary (Model (5)). This implies that the uncertainty about what drives the earnings surprise at the parent level is partly resolved when the subsidiary discloses earnings surprises and that this additional subsidiary information is still valuable to the parent's investors. Extending the controls in Model (6) with firm characteristics, parent-industry fixed effects, and link (parentsubsidiary) industry fixed effects yields similar results ( $0.5 \%$ abnormal return). The parent's investors hence react instantaneously to the disclosure of earnings surprises of both the parent and the subsidiary and there is no evidence of any delayed reaction for the case where the parent is the first announcer (Models (7) and (8)).

News related to complex ownership links may require more effort to process as opposed to news from stand-alone firms. Similarly, news from geographically and operationally diversified firms may also be 
more difficult to collect and analyze. A subsidiary's earnings surprise announcement sheds light on the breakdown of the parent's performance. The total parent's investor reaction is about $1.28 \%$ $(=0.96 \%+0.32 \% \%$; models (1) and (5), and similar numbers are obtained in models (2) and (6) which combine to $1.23 \%)$. Hence, $75 \%(=0.96 \% / 1.28 \%)$ of the total information is processed at the parent's announcement and $25 \%$ at the subsidiary's. These combined returns are close to the parent's investor reaction when the earnings surprise announcements are made by the parent and subsidiary on the same day (1.35\%, Model (1) in Table 5). The results remain qualitatively the same when we control for the parent's and link characteristics, and link industry fixed effects (columns (2) and (6)).

To sum up, when the parent releases its earnings first, parent's investors react both to their own firm's earnings announcements and to those of the subsidiary, which implies that the latter announcement still contains some additional information not yet priced by parent's investors. This finding supports the enhanced transparency conjecture for parent's investors in that corporate networks provide more information to investors than stand-alone firms.

\section{[Insert Table 6 about here]}

\section{Subsidiary's investor reactions}

In panel B of Table 6, we test whether the subsidiary's investors react to the information released by the parent when it discloses prior to its subsidiary. As subsidiary's earnings are consolidated in the parent's earnings, it would be rational for subsidiary's investors to immediately incorporate earnings surprise information released by the parent into the subsidiary's stock price. However, we do not find any economically or statistically significant subsidiary's price reaction to the parent's announcement - neither immediately (Models (1) and (2)) nor with a delay (Models (3) and (4)). The subsidiary's investors only react to their own firm's earnings announcements. Then, the response is both immediate (1.5\% in Models (5) and (6)), and with delay (Model (7), even if the last result is not sustained in Model (8)). In contrast to parent's investors, the subsidiary's investors only react to the subsidiary's announcement, ignoring the predictive information released at the parent level. This lack of stock price reaction implies that the subsidiary's investors fail to see how their firm is embedded in the corporate network. This finding confirms our hypothesis of subsidiary's investor unawareness about ownership links.

So, in the case where the parent announces first, the parent's investors incorporate information beyond that of the parent into the share prices, which implies that the subsidiary's earnings announcement adds value and enhances the transparency about the parent company. The subsidiary's investors only react to the information of the subsidiary itself and seem to be myopic towards predictive surprise news from the parent. 


\subsubsection{The subsidiary announces first}

We now turn to the case where a subsidiary's earnings announcement is scheduled prior to that of the parent. We expect that the subsidiary also conveys predictive information for the parent's investors. The signal would be particularly informative when the subsidiary's earnings constitute a large part of the parent's consolidated earnings. Thus, we expect the parent's investors to react twice: First, at the subsidiary's earnings surprise announcement, and then at the parent's disclosure. We expect the subsidiary's investors to respond to the disclosure of their own firm but not to that of the parent because, in principle, all relevant information for the subsidiary's investors is already released at this first announcement date.

\section{Parent's investor reactions}

Panel A of Table 7 reports the parent's investor reaction to the subsidiary's and parent's earnings surprises when the subsidiaries announce first. At the subsidiary's announcement, the parent's stock prices immediately react by on average $0.3 \%$ (Model (1)), but most of the information is processed with delay over the period [2;60] days as the stock prices then still increase by $2.8 \%$ (Models (3) and (4)). When the subsidiary has announced first and then the parent discloses a strong positive earnings surprise, the parent's stock prices immediately incorporate this positive news (with 1.2\% Models (5) and (6)), but again keep adjusting over the subsequent period (Models (7) and (8) exhibit a significantly positive PEAD of 2\%).

Our findings highlight that when the subsidiary announces first, the parent's investors seem myopic: They react with delay to both their own earnings announcements and those of the affiliated company. This suggests that at least some investors in the parent do not seem aware of the ownership connection with the subsidiary, or are unable to swiftly interpret information related to corporate complexity. We investigate these two potential mechanisms in tables 8 and 9.

\section{[Insert Table 7 about here]}

\section{Subsidiary's investor reactions}

Panel B of Table 7 reveals that at a subsidiary's announcement, its stock price on average immediately reacts (by about $+2 \%$ ) to the unexpected positive news (Models (1) and (2)), and keeps adjusting upwards by another 3\% over the subsequent period (Models (3) and (4)). Most of the information is hence seeping in the stock prices with a delay. Models from (5) to (6) show that the subsidiary's stock price does not immediately respond to the parent's surprise earnings announcement (which occurs at a stage subsequent to those of the subsidiaries) - there is only a weakly significant PEAD that disappears when controlling for various characteristics of the links.

There are several reasons why unawareness of ownership links may be more severe for a subsidiary investor. Whereas a parent investor has indirectly invested in the subsidiary (through the parent) and the subsidiary's earnings directly contribute to the parent's results, a subsidiary's investor - by holding a stake in only the subsidiary - has not invested in the parent. Moreover, it is probably easier to have a broad picture of 
a complex group when investing in the head rather than in a part of the group. Parents release earnings that consolidate the earnings of the publicly listed subsidiary and of the privately-owned subsidiaries and divisions for which no public separate earnings announcement is required. Hence, while it may be relatively straightforward to incorporate a subsidiary's information into the share price of the parent, it generally requires more sophisticated analysis to do the inverse and interpret the impact of earnings information of the parent (which comprises information of the network of connections) for a subsidiary's share price. Hence, from the point of view of a subsidiary's outside investors, although the parent company's news is disclosed first and contains predictive information about the subsidiary's earnings, this information may not be easy to disentangle from other entities' performance. Another reason for the absence of subsidiary's share price response at the parent's earnings announcement may be related to lower liquidity of the subsidiary's stock because of concentrated ownership and a smaller free float, which may coincide with fewer institutional investors. If a majority of the shareholders in the subsidiary are non-sophisticated investors, the reaction to announcements, especially for complicated firms, may not happen or may be understandably delayed - a point we will revisit to in the next section.

Overall, our results highlight that when a subsidiary announces first, the information value seems blurred and more difficult to understand, and hence triggers share price reactions with a delay, whereas when the parent announces first, the reactions are immediate in these cases: parent's reaction to parent's announcement, parent's reaction to subsidiary's announcement, subsidiary's reaction to subsidiary's announcement.

\subsection{Channels of Investor Unawareness}

In this subsection, we focus on parent's investor reaction to the subsidiary's announcement when the subsidiary releases its earnings first, and we investigate potential reasons why information is incorporated with delay. ${ }^{10}$ We first conjecture that the delayed reaction may be induced by characteristics and the complexity of corporate networks. Then, we test whether the delayed reaction depends on the level of investor sophistication.

\subsubsection{Corporate complexity}

Panel A of Table 8 reports the immediate and delayed parent's investor reactions to the subsidiary's announcement when the parent and the subsidiary are located in the same or different countries. We find that parent's investors do not immediately incorporate predictive information released by a subsidiary located in a different country; the information is then priced with delay. By contrast, parent's investors incorporate part of the information immediately. Similarly, in Panel B, we find that parent's investors immediately and

\footnotetext{
${ }^{10}$ We also test subsidiary's investor reaction to parent company's announcement when the parent releases its earnings first. We find that the absence of subsidiary's investor reaction is not influenced by the characteristics of the corporate network and the level of subsidiary's investor sophistication.
} 
significantly react to directly owned subsidiaries (while part of the information is also priced later), but when the subsidiary is controlled through several layers of intermediate firms, the parent's investors only react to subsidiary's earnings surprise with delay. So, Panel A and B suggest that the complexity induced by geographical diversification and by indirect ownership makes investors more myopic.

When the parent and subsidiary share part of their corporate names, the link between these firms may be easier to identify. Still, Panel $\mathrm{C}$ shows that the corporate name does not seem to have an impact in that the reaction to the earnings announcement takes place with a delay for both subsamples. In Panel D, we distinguish between the cases where the parent controls more or less than $50 \%$ of the subsidiary' equity and between the cases whereby the relative size of the subsidiary is higher or lower than the median. Stronger control and a larger relative importance of the subsidiary may eliminate possible inattention and trigger immediately price reactions to the release of information. However, for both sets of subsamples we do not find an immediate price reaction, but only a delayed reaction (which is why we show the whole time window of 60 days). The difference between the price reactions of the subsamples is not statistically significant.

[Insert Table 8 about here]

\subsubsection{Investor sophistication}

Abnormal returns around earnings announcements are presumably the effect of investors who modify their holding positions in reaction to firms' prospects. Investors are more likely to incorporate this source of information when they closely follow the company, and are sophisticated and professional investors. However, even institutions can be passive investors that do not closely manage their portfolio (Appel, Gormley, and Keim, 2016). We test this conjecture by relating parent's delayed reaction to the subsidiary's release of predictive information in the context of the presence of institutional and common owners. Fifty-eight percent of parent companies and 50\% of subsidiaries have at least one institutional investor. Investors in the parent who also invest in the subsidiary hold on average $3.2 \%$ in the subsidiary.

Table 9, columns (1) to (4), compares parent's investor reaction to the subsidiary's announcement when the parent has at least one institutional investor. The presence of at least one institutional investor triggers an immediately price reaction, which is absent when there is no institutional investor. For both subsamples, there is a PEAD. In columns (5) and (6), we focus on parents with large institutional ownership with large being defined as at least $5 \%$ and $10 \%$, respectively. We find that over the period going up to 60 days after the announcement, more information is incorporated when institutional investors represent a larger part of the company's capital. Finally, in columns (7) and (8), we compare parent's price reaction when at least one institutional investor of the parent also owns shares in the subsidiary. Indeed, common institutional owners may be less myopic about ownership ties, as they at least know about the existence of the subsidiary (Merton, 1987; Azar, Schmalz, and Tecu, 2016; Gilje, Gormley, and Levit, 2017). Still, we find that there is no immediately price reaction for either subsample and that the total abnormal returns (over 60 days) are 
somewhat larger in presence of institutional common investors, although the difference between the abnormal returns is not significantly different from zero. The evidence suggests that institutional investors are not quicker to price earnings surprise, and may not be more aware of ownership connections between parents and subsidiaries.

\section{[Insert Table 9 about here]}

\section{Robustness Checks}

\subsection{Endogeneous Strategic Announcement Timing}

The strategic timing literature posits that managers can exploit investor inattention by scheduling their earnings announcements. If the managers of parents and subsidiaries know that the immediate and delayed stock price responses will differ based on which of the affiliated companies first announces positive or negative surprises, they may set up relative announcement timing strategies and hence coordinate their announcements. Managers could schedule the announcement of good-news-subsidiaries first, and bad-newssubsidiaries after the parent company's announcement. By means of Heckman sample selection models, we test possible strategic timing by examining whether stock price reactions to earnings surprises (stage 2 in the models of Table 10) are affected by announcement timing (stage 1). The results shown in columns (1) to (4) are robustness tests of parent's and subsidiary's investor reactions when their announcements are scheduled on the same or on different days. Columns (5)-(7) show the results of a model which conditions on the subsidiary announcing prior to the parent (relative to the inverse case).

Our findings reveal that the choice to schedule a parent's and subsidiary's earnings surprise announcements on the same day does not affect the way the parent's and subsidiary's investors react to the announcements (in columns (2) and (4)): Both instantaneous reactions are significantly positive and the longterm reactions (not shown) are insignificant as in Table 5. From columns (1) and (3), we learn that earnings announcements are more likely to be scheduled on the same day when the subsidiary is relatively large, the parent owns a larger stake in its subsidiary, when the subsidiary is directly controlled by the parent (without intermediate investment vehicles), when parent and subsidiary operate in different industries, and when they share part of a corporate name.

While we tested in columns (1) to (4) the simultaneous versus staggered announcement, we now focus on robustness of a parent's immediate and delayed reaction to the subsidiary's earnings announcement subject to the possibly endogeneous choice of scheduling the subsidiary's announcement first relative to the choice of having the parent announce first. We find that the parent's investor reaction remains unchanged (relative to the findings in Table 5) when controlling for the announcement timing. ${ }^{11}$ In column (5), we

${ }^{11}$ We do not report the robustness test of subsidiary's investor reaction to the parent's announcement since no economically and statistically reaction was found - see Table 6 (Panel A) and Table 7 (Panel B). 
report the first stage and find that the choice to schedule the subsidiary's announcement first mainly depends on the link characteristics. Furthermore, the subsidiary's announcement is more likely to be scheduled first when the parent's and subsidiary's surprise earnings announcements are similar (both are in the two top or two bottom quantiles of their surprise earnings distributions). ${ }^{12}$

Overall, we fail to find evidence that strategic timing affects the investor reactions to the parent's and subsidiary's surprise earnings.

\section{[Insert Table 10 about here]}

\subsection{Tunneling and Parents' Expropriation Behavior}

We interpret the absence of a subsidiary's investor reaction to the surprise earnings announcement by a parent who announces first, as resulting from investor unawareness of the ownership link. However, an alternative explanation could be fear of tunneling. The rationale is the following: the parent announces a positive earnings surprise, but even if the subsidiary's investors are aware of the ownership link and expect that the positive earnings at the level of the parent result from the subsidiary, they may be still skeptical about whether this news is positive for the subsidiary. A positive earnings surprise could for instance reflect that the parent is able to extract earnings from the subsidiary by conducting self-dealing transactions at the expense of the subsidiary's investors. Therefore, positive earnings surprises at the parent level may result from expropriation decisions by the parent, leading to reduced earnings at the level of the subsidiary. Likewise, an announcement of negative earnings by the parent may indicate that the parent may be enticed to correct the negative earnings by subsequently extracting rents from a well-performing subsidiary. To check whether our results could be due to 'tunneling', we include legal variables as instruments for the potential for expropriation behavior. We use the Djankov et al. (2008) anti-self-dealing index that measures the legal protection of minority investors against self-dealing and expropriation by corporate insiders, and interact the index with the Surprise Top Two Quantiles variable. We find that a subsidiary's investor reaction to the parent's surprise earnings announcements (that are disclosed prior to those of the subsidiary) are statistically and economically insignificant. ${ }^{13}$ We also use an enforcement index (also by Djankov et al. (2008)) that measures the extent to which contracts are enforced in a court of law. We re-estimate our models by including the interaction of the surprise earnings measure with the public enforcement index and do not find any evidence that our findings are due to potential tunneling.

\footnotetext{
${ }^{12}$ The benchmark for these variables is that one or both of the surprise earnings announcements are in the middle quantiles. Many different robustness tests on these variables (e.g. continuous variables on the surprise earnings of parent and subsidiary, positive (negative) surprise earnings of parent and subsidiary, etc.) do not affect the findings in stage 2 .

${ }^{13}$ Table available on request.
} 


\subsection{Internal Capital Markets}

The investor response to surprise earnings announcements may depend on the existence of internal capital markets whereby surpluses in one division are used to fund capital needs in other divisions. For instance, when a subsidiary announces a positive earnings surprise, this may benefit the entire corporate group as the parent could redistribute excess funds to growth-oriented subsidiaries. The parent's response to the positive earnings surprise of the subsidiary could be stronger if the parent's performance (which was announced first) was poor. Conversely, a negative earnings surprise by the subsidiary may reduce the effectiveness of the internal capital market as redistribution may be more difficult for the parent. To tackle this question, we examine whether investors, observing that their own firm has incurred a negative result (and is a first announcer), react differently to the second announcement (that of the affiliated firm). We include in our regressions the variable Parent Neg. Earnings which equals one when the parent released negative actual earnings and zero otherwise and then study the response by parent's investors to a positive earnings surprise disclosed by the subsidiary in a context of growth/value firms (as proxied by Tobin's Q).

Model (1) of Table 11 confirms the positive price reaction by the parent when the subsidiary's earnings surprise is in the top two quantiles of its distribution, which we have shown in Panel A of Table 6. Model (2) reveals that the parent's investor reaction to the subsidiary's announcement is much stronger when the parent had announced negative earnings earlier on (at 1\%) as captured by the interaction term.

We further verify whether a parent's stock price reaction depends on the investment opportunities of parent and subsidiary, as proxied by their market-to-book ratios $(Q)$. In model (3), we interact a parent's negative earnings with the subsidiary's Surprise Top 2 Quantiles dummy and the subsidiary's Q. We find that this triple interaction is negative such that the effect of the interaction term negative earnings-positive surprise declines: the positive response of the parent with negative earnings to a positive surprise at the subsidiary level is smaller when that subsidiary has high growth opportunities (which may require the subsidiary to invest more and such that less funds may be transferred to the parent which may come at the detriment of the parent's and the other subsidiaries' immediate investment policies).

In Model (4), we run a similar regression but now substitute the subsidiary's Q by the difference between the subsidiary's and parent's Q (dQ) and examine whether the interaction of the parent's negative earnings with the subsidiary's positive surprise is affected by the triple interaction term that includes dQ. We find similar results in that the positive parent investor response to the subsidiary's positive surprise when the parent has negative earnings is smaller when the subsidiary has high and the parent low growth opportunities (high versus low Q). Another robustness test to Model (3) is presented in Model (5) where we substitute the subsidiary's Q by a dummy variable that equals one if the subsidiary's $Q$ is higher than that of the parent. We find similar results. 
These findings suggest that the magnitude of the stock price reaction to a subsidiary's earnings surprise depends on the parent's earnings and the growth opportunities of the subsidiary relative to those of the parent, which in turn suggests that the existence of internal capital markets could affect price responses.

[Insert Table 11 about here]

\subsection{Confounding Events}

When the subsidiary's announcement is scheduled first, parents on average release their earnings 13 calendar days later. The delayed parent's investor reaction to the subsidiary's announcement (Table 7, Panel A) may not be a post-earnings announcement drift but could be caused by the earnings announcement of the parent itself, which would misdirect our conclusions about the parent's investor ability (not) to perceive ownership connections.

In order to address this issue, we first rerun our tests and include a dummy variable equal to one if the parent announces earnings within the 60 trading days after the subsidiary's announcement, which is the period over which we calculated the PEAD. We find that our results about the parent's investor reaction are robust to the inclusion of this contamination dummy (Table 12, Model (1)).

Second, we rerun the same test on different post-announcement windows with subsamples unaffected by the subsequent parent's announcement. For example, Table 12, Model (2) tests the parent's investor reaction to the subsidiary's announcement over a 10-day window; the delayed investor reaction is therefore calculated for a period of $[2 ; 10]$ days and the test is performed only on parent-subsidiary annual announcement observations where the parent announces at least 10 trading days subsequent to the subsidiary. Models (3), (4), and (5) report similar tests for the delayed investor reaction calculated over [2;20], [2;30], and [2;40] windows, respectively whereby the parent does not release its earnings within the aforesaid windows. As the sample size significantly declines, we do not restrict the sample to the cases where parent and subsidiary have a common financial year, but add the dummy variable Same Financial Year. In addition to the usual control variables (parent's and link characteristics), we estimate the models by including link fixed effects and time (year, month, and day-of-the-week) fixed effects.

We find that parent's investor reactions to the subsidiary's announcements remain statistically and economically significant when controlling for announcement contamination. Furthermore, we confirm that a subsidiary's earnings surprise is only gradually priced over time by parent's investors.

[Insert Table 12 about here]

\subsection{Investors Reactions in Multinational Corporations}

About $28 \%$ of parents and subsidiaries operate in different countries and may be the product of unobservable considerations related for instance to geographic synergies, international diversification needs. An ideal specification to account for any kind of endogeneous complementarities of the group structure 
would include link-country $\mathrm{x}$ industry fixed effects. However, such specification is not identifiable with our sample as we do not have enough variation within parent-subsidiary-country-industry. Our baseline models include link industry SIC-2 fixed effects (Tables 6 and 7), and we report in Table 13 the same models with link (parent-subsidiary) country fixed effects instead.

For each combination, we look at the immediate and the delayed response to the event. For models that test investor reactions to earnings surprises of the company they have invested in, we control for company's characteristics and country fixed effects. For models that test investor reactions to earnings surprises of the affiliated company we include company characteristics, link (parent-subsidiary) control variables and link (parent-subsidiary) country fixed effects. We also include time (year, month, and day-ofthe week) fixed effects.

Overall, we find very similar results as reported above. More specifically, parent's investors react immediately and fully to their own earnings announcements (Panel A, models (1)-(2)) as well as to the subsidiary's when the parents disclose first (Panel A, model (3)). As for subsidiary's investors, they still do not incorporate predictive information contained in the parent's earnings released first (Panel A, models (5)(6)), but incorporate all the information at and subsequent to the subsidiary's announcement (Panel A, models (8)-(9)).

In panel B, we report investor reactions when subsidiary's earnings are released first. Parent's investors do react immediately at the subsidiary's announcement, but continue to incorporate information up to 60 days after the announcement (Panel B, models (1)-(2)). At the parent's announcement, the parent's investors immediately and fully incorporate the news into stock price (Panel B, models (3)-(4)). Subsidiary's investors also react to their own announcement, but do not immediately incorporate parent's news.

\section{[Insert Table 13 about here]}

\section{Conclusion}

We have examined the impact of ownership complexity in corporate networks on investor reactions to corporate news by studying whether the release of unanticipated information on earnings by affiliated firms affects the stock prices of those affiliated companies. We label the apex company as the parent that is linked to what we call a listed 'subsidiary' and the link is based on direct or indirect equity stakes of minimally $20 \%$ (which is a minimal threshold for consolidation under IFRS rules).

When the parent releases its earnings prior to that of the subsidiary, the parent's investors react both to the surprise earnings announcement of their own company and to the subsequent announcement by the subsidiary, which implies that the latter announcement still contains additional information not yet priced at the parent's initial announcement. These findings suggest that the network induces an enhanced transparency for investors who comprehend the ownership links. In contrast, the subsidiary's investors only react to the subsidiary's announcement, ignoring the predictive information released at the parent's level (at 
an earlier stage). This suggests that the subsidiary's investors may be myopic towards the ownership relation of the subsidiary with its parent company. When the subsidiary is the first to announce its (unanticipated) earnings, both the subsidiary's and parent's investors immediately incorporate this information in the share prices, but do so only partially as there is a post-earnings announcement drift which also suggests a myopic framework.

The explanations are that investors may have a blind spot or are myopic in the sense that they do not or at least not clearly observe the internal structure of the corporate group. The inattention is worsened by geographical diversification of affiliated firms and by the use of intermediate investment vehicles between parent and subsidiary (indirect ownership), but cannot be explained by strategic timing of the disclosure of earnings surprises (as the timing of the announcement may be induced by good or bad news), investor inattention induced by a day-of-the-week effect or seasonalities, possible expropriation of a subsidiary's performance by a parent (tunneling), internal capital markets, or synergy-related explanations across industries. 


\section{References}

Almeida, H., Kim, C. S., \& Kim, H. B. (2015). Internal capital markets in business groups: Evidence from the Asian financial crisis. The Journal of Finance, 70(6), 2539-2586.

Almeida, H., Park, S. Y., Subrahmanyam, M. G., \& Wolfenzon, D. (2011). The structure and formation of business groups: Evidence from Korean chaebols. Journal of Financial Economics, 99(2), 447-475.

Anjos, F., \& Fracassi, C. (2015). Shopping for information? Diversification and the network of industries. Management Science, 61(1), 161-183.

Appel, I. R., Gormley, T. A., \& Keim, D. B. (2016). Passive investors, not passive owners. Journal of Financial Economics, 121(1), 111-141.

Atanasov, V., Boone, A., \& Haushalter, D. (2010). Is there shareholder expropriation in the United States? An analysis of publicly traded subsidiaries.

Azar, J., Schmalz, M. C., \& Tecu, I. (2016). Anti-competitive effects of common ownership, Working Paper, Ross School of Business Nr. 1235.

Bagnoli, M., Kross, W., \& Watts, S.G., (2002). The Information in Management's Expected Earnings Report Date: A Day Late, a Penny Short. Journal of Accounting Research 40, 1275-1296.

Bailey, W., Karolyi, G. A., \& Salva, C. (2006). The economic consequences of increased disclosure: Evidence from international cross-listings. Journal of Financial Economics, 81(1), 175-213.

Barber, B. M., De George, E. T., Lehavy, R., \& Trueman, B. (2013). The earnings announcement premium around the globe. Journal of Financial Economics, 108(1), 118-138.

Barinov, A., Park, S. S., \& Yildizhan, C. (2016). Firm Complexity and Post-Earnings-Announcement Drift. Available at SSRN 2360338.

Begley, J., and P. E. Fischer. (1998). Is there Information in an Earnings Announcement Delay? Review of Accounting Studies, 347-363.

Belenzon, S., Hashai, N., \& Patacconi, A. (2017). The Architecture of Attention: Group Structure and Subsidiary Autonomy.

Berger, P. G., \& Ofek, E. (1995). Diversification's effect on firm value. Journal of Financial Economics, 37(1), 39-65.

Bernard, V. L., \& Thomas, J. K. (1989). Post-Earnings-Announcement Drift: Delayed Price Response or Risk Premium? Journal of Accounting Research, 27, 1-36.

Beuselinck, C., Cascino, S., Deloof, M., \& Vanstraelen, A. (2014). Earnings Management within Multinational Corporations. Available at SSRN 1599678.

Boulland, R., \& Dessaint, O. (2017). Announcing the Announcement. Journal of Banking and Finance, 82, 59-79.

Cao, J., Chordia, T., \& Lin, C. (2016). Alliances and Return Predictability. Journal of Financial and Quantitative Analysis, 51(05), 1689-1717.

Claessens, S., Djankov, S., \& Lang, L. H. (2000). The separation of ownership and control in East Asian corporations. Journal of Financial Economics, 58(1), 81-112.

Cohen, L., \& Frazzini, A. (2008). Economic links and predictable returns. The Journal of Finance, 63(4), 1977-2011.

Cohen, L., \& Lou, D. (2012). Complicated firms. Journal of Financial Economics, 104(2), 383-400.

DeFond, M., Hung, M., \& Trezevant, R. (2007). Investor protection and the information content of annual earnings announcements: International evidence. Journal of Accounting and Economics, 43(1), 37-67.

DellaVigna, S., \& Pollet, J. M. (2009). Investor inattention and Friday earnings announcements. The Journal of Finance, 64(2), 709-749.

Djankov, S., La Porta, R., Lopez-de-Silanes, F., \& Shleifer, A. (2008). The law and economics of selfdealing. Journal of Financial Economics, 88(3), 430-465. 
Doyle, J. T., \& Magilke, M. J. (2009). The timing of earnings announcements: An examination of the strategic disclosure hypothesis. The Accounting Review, 84(1), 157-182.

Dyck, A., \& Zingales, L. (2004). Private benefits of control: An international comparison. The Journal of Finance, 59(2), 537-600.

Faccio, M., \& Lang, L. H. (2002). The ultimate ownership of Western European corporations. Journal of Financial Economics, 65(3), 365-395.

Gilje, E., Gormley, T., \& Levit, D. (2017). The rise of common ownership, Working paper, Wharton School.

Glattfelder, J. B., \& Battiston, S. (2009). Backbone of complex networks of corporations: The flow of control. Physical Review E, 80(3), 036104.

Gopalan, R., Nanda, V., \& Seru, A. (2007). Affiliated firms and financial support: Evidence from Indian business groups. Journal of Financial Economics, 86(3), 759-795.

Hirshleifer D., Lim, S. S., \& Teoh, S. H. (2009). Driven to distraction: Extraneous events and underreaction to earnings news. The Journal of Finance, 64(5), 2289-2325.

Holderness, C. G. (2009). The myth of diffuse ownership in the United States. Review of Financial studies, 22(4), 1377-1408.

Hung, M., Li, X., \& Wang, S. (2014). Post-earnings-announcement drift in global markets: Evidence from an information shock. Review of Financial Studies, 28, 1242-1283.

Huang, X. (2015). Thinking Outside the Borders: Investors' Underreaction to Foreign Operations Information. Review of Financial Studies, 28(11), 3109-3152.

Johnson, S., La Porta, R., Lopez-de-Silanes, F., \& Shleifer, A., 2000. Tunneling. American Economic Review 90, 22-27.

Johnson, T.L., \& So, E.C., (2017). Time Will Tell: Information in the Timing of Scheduled Earnings News. Journal of Financial and Quantitative Analysis, forthcoming.

Kalemli-Ozcan, S., Sorensen, B., Villegas-Sanchez, C., Volosovych, V., \& Yesiltas, S. (2015). How to construct nationally representative firm level data from the ORBIS global database (No. w21558). National Bureau of Economic Research.

Laeven, L., \& Levine, R. (2008). Complex ownership structures and corporate valuations. Review of Financial Studies, 21(2), 579-604.

Lamont, O. (1997). Cash flow and investment: Evidence from internal capital markets. The Journal of Finance, 52(1), 83-109.

Lamont, O. A., \& Thaler, R. H. (2003). Can the Market Add and Subtract? Mispricing in Tech Stock Carveouts. Journal of Political Economy, 111(2), 227-268.

La Porta, R., Lopez-de-Silanes, F., Shleifer, A., \& Vishny, R. (2000). Investor protection and corporate governance. Journal of Financial Economics, 58(1), 3-27.

Maksimovic, V., \& Phillips, G.M., 2013. Conglomerate Firms, Internal Capital Markets, and the Theory of the Firm. Annual Review of Financial Economics 5, 225-244.

Massa, M., \& Rehman, Z. (2008). Information flows within financial conglomerates: Evidence from the banks-mutual funds relation. Journal of Financial Economics, 89(2), 288-306.

Massa, M., \& Žaldokas, A. (2016). Information transfers among co-owned firms. Journal of Financial Intermediation.

Merton, R. C. (1987). A simple model of capital market equilibrium with incomplete information. The Journal of Finance, 42(3), 483-510.

Michaely, R., Rubin, A., \& Vedrashko, A. (2014). Corporate governance and the timing of earnings announcements. Review of Finance, 18(6), 2003-2044.

Michaely, R., Rubin, A., \& Vedrashko, A. (2016). Further evidence on the strategic timing of earnings news: Joint analysis of weekdays and times of day. Journal of Accounting and Economics, 62(1), 24-45.

Penman, S.H., (1987). The distribution of earnings news over time and seasonalities in aggregate stock returns. Journal of Financial Economics 18, 199-228. 
Ramnath, S. (2002). Investor and analyst reactions to earnings announcements of related firms: An empirical analysis. Journal of Accounting Research, 40(5), 1351-1376.

Shin, H. H., \& Stulz, R. M. (1998). Are internal capital markets efficient?. The Quarterly Journal of Economics, 113(2), 531-552.

Slovin, M. B., \& Sushka, M. E. (1997). The Implications of Equity Issuance Decisions within a ParentSubsidiary Governance Structure. The Journal of Finance, 52(2), 841-857. 


\section{Appendix A. Variable description}

\begin{tabular}{|c|c|}
\hline Variable & Description \\
\hline \multicolumn{2}{|c|}{ Earnings Announcement Characteristics } \\
\hline Earnings Surprise & $\begin{array}{l}\text { Parent's or Subsidiary's Earnings Surprise: difference between actual earnings for the current } \\
\text { year and the median analyst forecast (whereby only those forecasts within a six month period } \\
\text { up to three days before the earnings announcement are retained), divided by the share price five } \\
\text { days before the announcement date. Only one forecast per analysts is taken. Source: I/B/E/S } \\
\text { Detail History file }\end{array}$ \\
\hline Top Two Quantiles & $\begin{array}{l}\text { Dummy variable equal to one if an earnings surprise falls within the top two quantiles of its } \\
\text { distribution, and zero otherwise if an earnings surprise falls within the bottom two quantiles. } \\
\text { Distributions are split into } 11 \text { quantiles. The sixth quantile is the zero-surprise quantile. (See } \\
\text { section } 2.3 \text { for more details). Source: I/B/E/S Detail history file }\end{array}$ \\
\hline Contaminated Window & $\begin{array}{l}\text { Dummy variable equal to one if a subsidiary (parent) announces within the 60-day window } \\
\text { after the parent (subsidiary) has made an earnings announcement, and zero otherwise. Source: } \\
\text { I/B/E/S Detail history file; BvD Orbis }\end{array}$ \\
\hline Same Financial Year & $\begin{array}{l}\text { Dummy variable equal to one if a parent and its subsidiary close their financial year on the } \\
\text { same date, and zero otherwise. Source: } \mathrm{I} / \mathrm{B} / \mathrm{E} / \mathrm{S} \text { Detail history file; BvD Orbis }\end{array}$ \\
\hline Same Day & $\begin{array}{l}\text { Dummy variable equal to one if a parent and its subsidiary announce their earnings on the same } \\
\text { day, and zero otherwise. Source: } \mathrm{I} / \mathrm{B} / \mathrm{E} / \mathrm{S} \text { Detail history file; BvD Orbis }\end{array}$ \\
\hline Subsidiary First & $\begin{array}{l}\text { Dummy variable equal to one if a subsidiary announces its earnings prior to its parent } \\
\text { company, and zero otherwise. Source: } \mathrm{I} / \mathrm{B} / \mathrm{E} / \mathrm{S} \text { Detail history file; BvD Orbis }\end{array}$ \\
\hline Announcement Distance & $\begin{array}{l}\text { Logarithm of the number of calendar days between a parent's earnings announcement and its } \\
\text { subsidiary's. Source: I/B/E/S Detail history file; BvD Orbis }\end{array}$ \\
\hline Announcement Timing Change & $\begin{array}{l}\text { Dummy variable equal to one if, within a pair parent-subsidiary, there is a change in the order } \\
\text { of announcement between the years } \mathrm{t}-1 \text { and } \mathrm{t} \text {, and zero if there is no change (e.g. the subsidiary } \\
\text { announces first at } \mathrm{t}-1 \text { and } \mathrm{t} \text { ). } \\
\text { Source: } \mathrm{I} / \mathrm{B} / \mathrm{E} / \mathrm{S} \text { Detail history file; BvD Orbis }\end{array}$ \\
\hline Parent Neg. Earnings & $\begin{array}{l}\text { Dummy variable equal to one if the parent's realized earnings are negative, zero otherwise. } \\
\text { Source: I/B/E/S Detail history file }\end{array}$ \\
\hline \multicolumn{2}{|c|}{ Firm Characteristics (Parent or Subsidiary) } \\
\hline Nr. Analysts & $\begin{array}{l}\text { Number of earnings forecasts issued by analysts in the six months preceding the annual } \\
\text { earnings announcement and up to three days prior to the announcement. Source: I/B/E/S Detail } \\
\text { history file }\end{array}$ \\
\hline Is Illiquid & $\begin{array}{l}\text { Dummy variable equal to one if a company' stock displays more than } 50 \% \text { zero returns days in } \\
\text { a given year, and zero otherwise. Source: Datastream }\end{array}$ \\
\hline Market Value & $\begin{array}{l}\text { Logarithm of market capitalization at the end of the previous financial year. Source: } \\
\text { Datastream }\end{array}$ \\
\hline Has an Institutional Owner & $\begin{array}{l}\text { Dummy variable equal to one if at least one institutional owner owns an equity stake (of } \\
\text { minimally } 0.01 \% \text { ) in the company, and zero otherwise. Institutional owners include mutual } \\
\text { funds, pension funds, hedge funds, private equity funds, venture capital, banks, and insurance } \\
\text { companies. Source: BvD Orbis }\end{array}$ \\
\hline Nr. Institutional Owners & Number of institutional owners who own a stake of minimally $0.01 \%$. Source: BvD Orbis \\
\hline Nr. Institutional Owners $>1 \%$ & $\begin{array}{l}\text { Number of institutional owners who own an equity stake of minimally } 1 \% \text { in the company. } \\
\text { Source: BvD Orbis }\end{array}$ \\
\hline \% Institutional Ownership & $\begin{array}{l}\text { Total ownership percentage owned by institutional investors in the company. Source: BvD } \\
\text { Orbis }\end{array}$ \\
\hline Q & $\begin{array}{l}\text { Market-to-book ratio: market capitalization divided by book value of assets. Source: } \\
\text { Datastream }\end{array}$ \\
\hline dQ & $\begin{array}{l}\text { Difference between the subsidiary's and the parent's market-to-book ratios. Source: } \\
\text { Datastream }\end{array}$ \\
\hline iQ & $\begin{array}{l}\text { Dummy variable equal to one if the subsidiary's market-to-book is strictly greater than that of } \\
\text { the parent's, and zero otherwise. Source: Datastream }\end{array}$ \\
\hline Self-dealing Index & $\begin{array}{l}\text { Country-level index of ex-post control over self-dealing transactions (ranging from zero to } \\
\text { one); it represents the average of disclosure in periodic filings (e.g., annual reports) and ease of } \\
\text { proving wrongdoing. Ease of proving wrongdoing is the average of five variables as defined in } \\
\text { the source paper: (1) Disclosure in periodic filings, (2) Rescission, (3) Ease of holding } \\
\text { someone liable, (4) Ease of holding the approving body liable, (5) Access to evidence. Source: } \\
\text { Djankov et al. (2008) }\end{array}$ \\
\hline Public Enforcement Index & $\begin{array}{l}\text { Country-level variable ranging from } 0 \text { to } 1 \text {; one quarter point is added when each of the } \\
\text { following sanctions is available in response to disclosure and approval requirements as defined }\end{array}$ \\
\hline
\end{tabular}

${ }^{14}$ https://scholar.harvard.edu/shleifer/publications/law-and-economics-self-dealing 


\begin{tabular}{|c|c|}
\hline & $\begin{array}{l}\text { in the source paper: (1) fines for the approving body; (2) jail sentences for the approving body; } \\
\text { (3) fines; and (4) jail sentence. Source: Djankov et al. (2008) }\end{array}$ \\
\hline \multicolumn{2}{|c|}{ Link (Parent-Subsidiary) Characteristics } \\
\hline$\%$ Ownership & $\begin{array}{l}\text { Percentage of equity that a parent holds in a subsidiary at the end of the previous year. Source: } \\
\text { BvD Orbis }\end{array}$ \\
\hline Directly Owned & $\begin{array}{l}\text { Dummy variable equal to one if a parent holds a direct equity stake - not via intermediate } \\
\text { subsidiaries - in its subsidiary, and zero otherwise. Source: BvD Orbis }\end{array}$ \\
\hline Has a Common Analyst & $\begin{array}{l}\text { Dummy variable equal to one if at least one analyst follows both a parent company and its } \\
\text { subsidiary, and zero otherwise. Source: I/B/E/S Detail history file; BvD Orbis }\end{array}$ \\
\hline Common Name & $\begin{array}{l}\text { Dummy variable equal to one if the Jaro-Wicler string distance }{ }^{15} \text { between the parent's and } \\
\text { subsidiary's names is higher than } 0.75 \text {, and zero otherwise. Source: BvD Orbis }\end{array}$ \\
\hline Same Country & $\begin{array}{l}\text { Dummy variable equal to one if a parent and its subsidiary are located in the same country, and } \\
\text { zero otherwise. Source: BvD Orbis }\end{array}$ \\
\hline Same Industry & $\begin{array}{l}\text { Dummy variable equal to one if a parent and its subsidiary operate in the same industry (based } \\
\text { on the SIC } 2 \text { classification), and zero otherwise. Source: BvD Orbis }\end{array}$ \\
\hline Has a Common Owner & $\begin{array}{l}\text { Dummy variable equal to one if at least one institutional owner owns an equity stake in both a } \\
\text { parent company and its subsidiary, and zero otherwise. Source: BvD Orbis }\end{array}$ \\
\hline N. Common Owners & $\begin{array}{l}\text { Number of institutional owners by parent-subsidiary link, who own equity stakes in both a } \\
\text { subsidiary and its parent. Source: BvD Orbis }\end{array}$ \\
\hline \% Common Ownership & $\begin{array}{l}\text { The sum of the ownership stakes in a subsidiary held by institutional owners that also own } \\
\text { equity in the parent of that subsidiary. Source: BvD Orbis }\end{array}$ \\
\hline \multicolumn{2}{|l|}{ Fixed Effects } \\
\hline Link Country FE & Pair (parent-subsidiary) country fixed effects. \\
\hline Link Industry FE & Pair (parent-subsidiary) SIC 2-digit industry fixed effects. \\
\hline Link FE & Pair parent-subsidiary fixed effects. \\
\hline Industry FE & $\begin{array}{l}\text { Firm SIC 2-digit industry fixed effects. The aforesaid firm (parent or subsidiary) is the firm of } \\
\text { the investors studied reaction. }\end{array}$ \\
\hline Year + Month + Day FE & $\begin{array}{l}\text { Year of announcement fixed effects + Month of announcement fixed effects + Day of the week } \\
\text { announcement fixed effects. }\end{array}$ \\
\hline
\end{tabular}

${ }^{15}$ https://scholar.harvard.edu/jfeigenbaum/software/jaro-winkler-distance 


\section{Appendix B. Consolidation Rules around the World}

Since the end of the 1990s, the two predominant accounting standards are U.S. GAAP (Generally Accepted Accounting Principles) and IFRS (International Financial Reporting Standards) when both standard setters, IASB (International Accounting Standards Board) and FASB (Financial Accounting Standards Board), initiated a convergence project (PricewaterhouseCoopers, 2015). As of 2015, IFRS 10, Consolidated Financial Statements, defines consolidation rules in 114 countries (PricewaterhouseCoopers, 2016b). More generally, IFRS rules apply to all or most domestic publicly listed companies in a country. The adoption of the IFRS system is a voluntary decision by the legislative and regulatory authorities in individual countries. Neither the IFRS Foundation nor the IASB (an independent, private sector, and not-for-profit organization) has the authority to mandate or supervise adoption.

Currently, 41 out of 42 European countries require IFRS (PricewaterhouseCoopers, 2016b). The major convergence happened in 2005 when 7,000 European companies in 25 countries (including UK) simultaneously switched from national GAAP to IFRS. The same year, Australia, Hong Kong, New Zealand and South Africa also adopted IFRS. In 2007, Brazil, Canada, Chile, Israel and Korea established timelines to adopt IFRS, and in 2009, Japan approved an IFRS road map to permit voluntary adoption of IFRS. Today, only 24 countries have still not fully converged to IFRS, although 12 of them (including India and Japan) permit IFRS. Thailand and Indonesia are in the process of adopting IFRS, while other countries such as China and the US have their national accounting standards.

IFRS 10 on Consolidated Financial Statements (which replaced the consolidation rules defined in IAS 27) outlines the presentation of consolidated financial statements, requiring firms to consolidate the entities they control. IFRS 10 introduces a new definition of control, which requires an investor to consolidate an investee when it has all of the following attributes:

- "Power to direct the activities that significantly affect (the relevant activities that affect) the investee's returns

- Exposure, or rights, to variable returns from its involvement with the investee (returns must vary and can be positive, negative, or both)

- The ability to use its power over the investee to affect the amount of the investor's returns"

U.S. GAAP is the second most followed accounting standard. U.S. domestic companies whose securities are traded in public markets must comply with U.S. GAAP consolidation rules. Foreign companies whose securities are traded in the U.S. are permitted to choose between US GAAP or IFRS or their national GAAP. Nearly 500 foreign issuers in the U.S. use IFRS.

Some similarities exist between IFRS and U.S. GAAP related to consolidations. Both IFRS and U.S. GAAP use the notion of control to determine whether a reporting entity should consolidate another entity. However, there are differences in the definition of control such as the notion of de facto versus effective control (Ting, 2012). De facto control exists for instance in situations where a parent company may have control over another firm in spite of holding less than a 50\% voting interest and lacking legal or contractual rights that would permit the parent to control the other firm's voting power or board. Consequently, de facto control may exist in a situation in which a major shareholder holds a stake of less than $50 \%$ of the voting rights in another entity where the other ownership holdings are dispersed. IFRS require parent companies to consolidate de facto controlled subsidiaries, whereas U.S. GAAP recognizes only effective control. U.S. GAAP consolidation rules are therefore more restrictive than those of IFRS.

In a nutshell, both U.S. GAAP and IFRS require parent companies to consolidate subsidiaries (in which they own more than $50 \%$ of the voting rights). When it comes to associate entities, in which the parent owns between $20 \%$ and 50\%, IFRS standards require the parent to consolidate the entity if the company is presumably controlled by the parent ('de facto control'), whereas U.S. GAAP require to consolidate these 
entities only if the parent demonstrates the exercise of a significant influence ('effective control') through voting rights or board control. In either case, consolidated financial statements use the equity method.

As almost half of our sample consists of Asian parent companies, we discuss hereafter the consolidation rules for Asian countries where business groups most frequently occur (Korean Chaebols, Japanese Keiretsus, and Indian conglomerates).

Korea: All companies listed on the Korea Exchange are currently required to apply IFRS. In addition, IFRS is also required for financial institutions with publicly traded securities and state-owned companies.

Japan: Japanese GAAP was developed by the Accounting Standards Board of Japan (ASBJ) and resulted from an agreement between the ASBJ and the International Accounting Standards Board (IASB) aiming to make Japanese accounting standards converge to IFRS (Tokyo Agreement, 2007). The Japanese GAAP is not identical but largely equivalent to IFRS. Since 2010, Japanese companies have the choice between Japanese GAAP, IFRS, or US GAAP when issuing consolidated financial statements. As of January 2015, 62 of the largest firms companies (with over US\$650 billion of market capitalization on the Tokyo Stock Exchange) are using IFRS.

India (PricewaterhouseCoopers, 2016a): Consolidation in India is defined by the Securities and Exchange Board of India (SEBI), which requires all listed companies with subsidiaries to file consolidated financial statements to the stock exchanges. The SEBI requires those financial statements to be prepared in conformity with the Accounting Standards developed by the Institute of Chartered Accountants of India (ICAI) and approved by the Central Government. However, the SEBI has given the option to listed entities to prepare and file consolidated financial statements in conformity with IFRS.

\section{References}

Ting, A. (2012). The taxation of corporate groups under consolidation: an international comparison. Cambridge University Press.

IFRS (2015). IFRS as global standards. http://www.ifrs.org/Use-around-the-world/Documents/IFRS-asglobal-standards-Pocket-Guide-April-2015.PDF

PricewaterhouseCoopers (2016a). Indian Consolidation Rules. http://www.pwc.in/assets/pdfs/indiapublications-similarities-differences.pdf

PricewaterhouseCoopers (2016b). IFRS and U.S. GAAP: Similarities and Differences. http://www.pwc.com/us/en/cfodirect/assets/pdf/accounting-guides/pwc-ifrs-us-gaap-similarities-anddifferences-2016.pdf

PricewaterhouseCoopers (2015). IFRS and U.S. GAAP: Similarities and Differences. http://www.pwc.com/us/en/cfodirect/assets/pdf/accounting-guides/pwc-ifrs-us-gaap-similarities-anddifferences-2015.pdf 


\section{Table 1. Geographic Breakdown of Corporate Networks around the World}

The table reports the geographic dissection of the parent and subsidiary links. Pairs of publicly listed companies and subsidiaries are identified by means of ownership links in Bureau van Dijk's Orbis database for the period 2000 until 2016. The category Europe includes Albania, Austria, Belgium, Croatia, Cyprus, Czech Republic, Germany, Denmark, Spain, Finland, France, Ireland, Greece, Hungary, Italy, Lithuania, Luxembourg, The Netherlands, Norway, Poland, Portugal, Romania, Russia, Slovakia, Sweden, Switzerland, and Ukraine. Asia comprises China, Hong-Kong, Korea, India, Indonesia, Japan, Malaysia, Singapore, Thailand, Philippine, Pakistan, and Taiwan. The Americas include Canada, Latin America, and the Caribbean islands. The group Middle East includes Israel, Turkey, Lebanon, Oman, and Saudi. AU/NZ stands for Australia and New Zeeland.

\begin{tabular}{lccccccccc}
\hline \begin{tabular}{l} 
Subsidiary's \\
\multicolumn{1}{c}{ Country }
\end{tabular} & US & GB & Europe & Asia & Africa & Americas & Middle East & AU/NZ & Total \\
\hline US & 178 & 2 & 10 & 4 & 0 & 10 & 0 & 0 & 204 \\
GB & 17 & 16 & 5 & 4 & 4 & 7 & 1 & 1 & 55 \\
Europe & 15 & 9 & 256 & 12 & 0 & 9 & 3 & 0 & 304 \\
Asia & 15 & 19 & 41 & 1,189 & 1 & 23 & 2 & 3 & 1,293 \\
Africa & 5 & 21 & 21 & 1 & 40 & 0 & 1 & 0 & 89 \\
Americas & 24 & 10 & 32 & 52 & 3 & 125 & 1 & 3 & 250 \\
Middle East & 2 & 1 & 11 & 3 & 0 & 0 & 62 & 0 & 79 \\
AU/NZ & 1 & 2 & 5 & 7 & 3 & 3 & 1 & 23 & 45 \\
Total & 257 & 80 & 381 & 1,272 & 51 & 177 & 71 & 30 & 2,319 \\
\hline
\end{tabular}




\section{Table 2. Descriptive Statistics}

The table reports the distributional characteristics of parents and subsidiaries, and parent-subsidiary links. The sample of link-year observations includes links for which we could match earnings announcements of the parent and the subsidiary in a given year. Earnings announcements dates come from I/B/E/S and cover the period from January 2000 until December 2015. All numbers are in USD. Detailed variable descriptions and the data sources are offered in Appendix A.

\begin{tabular}{|c|c|c|c|c|c|c|}
\hline & N. Year-Obs. & Mean & Median & $\mathrm{Sd}$ & $\mathrm{P} 25$ & $\mathrm{P} 75$ \\
\hline \multicolumn{7}{|l|}{ Parent Companies' Characteristics } \\
\hline Market Value (USD 000,000) & 7,376 & 11.077 & 3.619 & 16.935 & 1.025 & 12.294 \\
\hline Total Asset (USD 000,000) & 7,376 & 26.421 & 7.516 & 44.576 & 2.138 & 26.479 \\
\hline Tobin's Q & 7,376 & 0.738 & 0.480 & 0.868 & 0.266 & 0.875 \\
\hline Is Illiquidity (\%) & 7,376 & 3.39 & 0 & 18.10 & 0 & 0 \\
\hline Nr. Analysts & 7,376 & 13.628 & 12 & 10.548 & 5 & 200 \\
\hline Has an Institutional Owner (\%) & 7,376 & 57.71 & 100 & 49.40 & 0 & 100 \\
\hline Nr. Institutional Owners & 7,376 & 25.542 & 7 & 36.501 & 0 & 40 \\
\hline Nr. Institutional Owners >1\% & 7,376 & 5.194 & 2 & 7.213 & 0 & 8 \\
\hline$\%$ Institutional Ownership & 7,376 & 15.53 & 0.37 & 21.60 & 0 & 26.41 \\
\hline Earnings Surprise & 7,376 & -0.004 & 0.000 & 0.072 & -0.005 & 0.005 \\
\hline \multicolumn{7}{|l|}{ Subsidiaries' Characteristics } \\
\hline Market Value (USD 000) & 14,110 & 3.100 & 0.650 & 7.692 & 0.179 & 2.310 \\
\hline Total Asset (USD 000) & 14,110 & 6.393 & 1.013 & 20.403 & 0.322 & 3.561 \\
\hline Tobin's Q & 14,110 & 0.946 & 0.570 & 1.186 & 0.302 & 1.087 \\
\hline Is Illiquidity (\%) & 14,110 & 5.59 & 0 & 22.98 & 0 & 0 \\
\hline Nr. Analysts & 14,110 & 7.853 & 5 & 8.322 & 2 & 11 \\
\hline Has an Institutional Owner (\%) & 14,110 & 50.41 & 100 & 50 & 0 & 100 \\
\hline Nr. Institutional Owners & 14,110 & 13.111 & 1 & 22.956 & 0 & 18 \\
\hline Nr. Institutional Owners $>1 \%$ & 14,110 & 3.232 & 0 & 5.800 & 0 & 4 \\
\hline$\%$ Institutional Ownership & 14,110 & 10.59 & 0 & 16.98 & 0 & 16.28 \\
\hline Earnings Surprise & 14,110 & -0.006 & 0.000 & 0.081 & -0.007 & 0.005 \\
\hline \multicolumn{7}{|l|}{ Links' Characteristics } \\
\hline Relative Market Value & 14,851 & 0.412 & 0.123 & 0.704 & 0.033 & 0.448 \\
\hline $\mathrm{dQ}=($ sub's $\mathrm{Q}-$ parent's $\mathrm{Q})$ & 14,851 & 0.326 & 0.116 & 1.160 & -0.115 & 0.517 \\
\hline $\mathrm{iQ}=($ dummy: sub's $\mathrm{Q}<$ parent's $\mathrm{Q})$ & 14,851 & 0.631 & 1 & 0.482 & 0 & 1 \\
\hline Directly Owned (\%) & 14,851 & 71.92 & 100 & 44.94 & 0 & 100 \\
\hline$\%$ Ownership & 14,851 & 48.28 & 45.54 & 22.42 & 29.90 & 60.40 \\
\hline Has a Common Analyst (\%) & 14,851 & 9.33 & 0 & 29.08 & 0 & 0 \\
\hline Named After $(\%)$ & 14,851 & 27.05 & 0 & 44.42 & 0 & 100 \\
\hline Same Industry (\%) & 14,851 & 42.05 & 0 & 49.37 & 0 & 100 \\
\hline Same Country $(\%)$ & 14,851 & 71.88 & 100 & 44.96 & 0 & 100 \\
\hline Has a Common Owner (\%) & 14,851 & 39.09 & 0 & 48.80 & 0 & 100 \\
\hline Nr. Common Owners & 14,851 & 4.68 & 0 & 10.45 & 0 & 4 \\
\hline$\%$ Common Ownership & 14,812 & 4.65 & 0 & 10.87 & 0 & 3.77 \\
\hline Announcement Timing Change & 14,851 & 0.659 & 1.000 & 0.474 & 0.000 & 1.000 \\
\hline
\end{tabular}


Table 3. Immediate and Delayed Reactions by Parent's and Subsidiary's Investors

The table presents results on investor reactions to earnings surprises (within the top two quantiles of the distribution). Buy-and-hold-abnormal returns (BHARs) are calculated using the market model over the trading day period ( $-300,-46$ days) and are measured over the $(0,+1)$ and $(+2,+60)$ event windows. Columns $(1-4)$ report results of parent investor reactions to the parent's announcement (1-2) and to subsidiary's announcement (3-4). Columns (5-8) report results of subsidiaries' investor reactions to the subsidiary's announcement (5-6), and to its parent's announcement (7-8). Parent controls include the parent's market value, the log of analyst coverage, the Tobin's $Q$, and a dummy variable equal to one if the firm's shares are liquid. Subsidiary's controls are the same as those of the parent (but applied to the subsidiary). Link controls are the companies' relative market value, percentage of common analysts, percentage of control held by the parent, a direct ownership dummy, dummy variables equal to one if parent and subsidiary are located in the same country, if they share part of the corporate name, and if the parent and its subsidiary have a common institutional investor. All specifications include link (parent-subsidiary) SIC2 industry fixed effects, and time fixed effects (year, month, and day-of-the-week). Robust $\mathrm{t}$-statistics are reported between brackets. *, **, and *** indicate significance at the $10 \%, 5 \%$, and $1 \%$ level, respectively.

[Table continued on next page] 
Table 3. Immediate and Delayed Reactions by Parent's and Subsidiary's Investors (Cont'd)

\begin{tabular}{|c|c|c|c|c|c|c|c|c|}
\hline \multirow{4}{*}{ Time window } & \multicolumn{4}{|c|}{ Parent's investor reaction } & \multicolumn{4}{|c|}{ Subsidiary's investor reaction } \\
\hline & \multicolumn{2}{|c|}{$\mathrm{P}^{\prime}$ announcement } & \multicolumn{2}{|c|}{$\mathrm{S}^{\prime}$ announcement } & \multicolumn{2}{|c|}{ own announcement } & \multicolumn{2}{|c|}{$\mathrm{P}^{\prime}$ announcement } \\
\hline & {$[0 ; 1]$} & {$[2 ; 60]$} & {$[0 ; 1]$} & {$[2 ; 60]$} & {$[0 ; 1]$} & {$[2 ; 60]$} & {$[0 ; 1]$} & {$[2 ; 60]$} \\
\hline & (1) & (2) & (3) & (4) & (5) & (6) & (7) & (8) \\
\hline \multirow{2}{*}{ Top Two Quantiles } & & & & & $0.0167 * *$ & & & \\
\hline & $\begin{array}{l}0.0138^{* * *-1} \\
(7.5132)\end{array}$ & $\begin{array}{l}0.0080 \\
(15024)\end{array}$ & $\begin{array}{l}0.0022 * * \\
(2.0634)\end{array}$ & $\begin{array}{c}0.0084 * \\
(1.7880)\end{array}$ & $(8.6718)$ & $(2.9846)$ & $\begin{array}{c}0.0002 \\
(0.1585)\end{array}$ & $\begin{array}{c}0.00 / 3 \\
(1.2868)\end{array}$ \\
\hline \multirow[t]{2}{*}{ Same Day } & 0.0031 & -0.0137 & 0.0005 & 0.0038 & -0.0028 & 0.0068 & -0.0009 & 0.0013 \\
\hline & (0.8209) & $(-1.4302)$ & $(0.2553)$ & $(0.4739)$ & $(-0.8369)$ & $(0.5425)$ & $(-0.2773)$ & $(0.1211)$ \\
\hline \multirow[t]{2}{*}{ Sub First } & -0.0035 & -0.0065 & -0.0000 & 0.0089 & 0.0030 & $0.0203 * *$ & -0.0017 & -0.0039 \\
\hline & $(-1.1782)$ & $(-0.8048)$ & $(-0.0297)$ & (1.3282) & $(1.2965)$ & (2.4031) & $(-1.0414)$ & $(-0.5664)$ \\
\hline \multirow[t]{2}{*}{ Same Fiscal Year } & 0.0041 & -0.0143 & 0.0009 & 0.0116 & -0.0000 & -0.0170 & $0.0041 *$ & 0.0126 \\
\hline & $(0.7979)$ & $(-1.2126)$ & $(0.4881)$ & (1.3175) & $(-0.0014)$ & $(-1.2760)$ & $(1.8425)$ & (1.2487) \\
\hline \multirow[t]{3}{*}{ Market Value } & 0.0010 & $0.0105^{* * *}$ & -0.0002 & $0.0108 * * *$ & $0.0016^{* *}$ & $0.0178 * * *$ & 0.0003 & $0.0157 * * *$ \\
\hline & (1.1764) & $(3.2346)$ & $(-0.2737)$ & $(4.2762)$ & $(2.3930)$ & (5.0945) & $(0.3932)$ & $(4.7524)$ \\
\hline & & & $\begin{array}{c}0.0030^{* * *} \\
*\end{array}$ & $0.0106 * *$ & 0.0021 & $0.0195 * *$ & & $0.0137 * * *$ \\
\hline Q & $(-0.0568)$ & $(1.9248)$ & (3.7016) & (2.4935) & $(1.5562)$ & (2.2440) & $(2.0851)$ & $(3.3539)$ \\
\hline \multirow[t]{2}{*}{ Is Illiquid } & -0.0009 & $-0.0407 * *$ & -0.0029 & $0.0757 * * *$ & -0.0001 & $0.0701 * * *$ & -0.0070 & $-0.0388^{*}$ \\
\hline & $(-0.1971)$ & $\begin{array}{c}(-2.4409) \\
-\end{array}$ & $(-0.9119)$ & $\begin{array}{c}(-3.1665) \\
-\end{array}$ & $(-0.0173)$ & $\begin{array}{c}(-4.0653) \\
-\end{array}$ & $(-1.4735)$ & $(-1.6936)$ \\
\hline \multirow[t]{2}{*}{ Nr. Analysts } & -0.0014 & $0.0151 * * *$ & -0.0010 & $0.0218^{* * *}$ & -0.0015 & $0.0235 * * *$ & -0.0008 & $-0.0185^{* * *}$ \\
\hline & $(-1.1707)$ & $(-3.2447)$ & $(-1.1727)$ & $(-5.7156)$ & $(-1.1314)$ & $(-5.3164)$ & $(-0.7470)$ & $(-4.0895)$ \\
\hline \multirow{3}{*}{$\begin{array}{l}\text { Relative Market } \\
\text { Value }\end{array}$} & & & & & & & & \\
\hline & & & 0.0013 & 0.0026 & & & 0.0005 & $-0.0092 * *$ \\
\hline & & & $(0.8828)$ & $(0.4830)$ & & & $(0.6281)$ & $(-2.2364)$ \\
\hline \multirow[t]{2}{*}{ \% Common Analysts } & & & 0.0039 & 0.0662 & & & -0.0092 & 0.0327 \\
\hline & & & $(0.4162)$ & (1.6145) & & & $(-0.9018)$ & (0.7813) \\
\hline \multicolumn{9}{|l|}{ Has a Common } \\
\hline \multirow[t]{2}{*}{ Owner } & & & -0.0010 & 0.0053 & & & 0.0003 & 0.0033 \\
\hline & & & $(-0.5949)$ & $(0.7564)$ & & & $(0.1543)$ & $(0.3592)$ \\
\hline \multirow[t]{2}{*}{$\%$ Ownership } & & & 0.0000 & 0.0000 & & & 0.0000 & 0.0001 \\
\hline & & & $(0.4865)$ & $(0.3183)$ & & & $(0.2401)$ & (0.7774) \\
\hline \multirow[t]{2}{*}{ Directly Owned } & & & -0.0007 & $-0.0123 *$ & & & $0.0036^{*}$ & -0.0114 \\
\hline & & & $(-0.4791)$ & $(-1.7232)$ & & & $(1.9556)$ & $(-1.5653)$ \\
\hline \multirow[t]{2}{*}{ Same Country } & & & -0.0018 & 0.0083 & & & -0.0001 & 0.0112 \\
\hline & & & $(-1.1988)$ & $(1.3121)$ & & & $(-0.0422)$ & $(1.1820)$ \\
\hline \multirow[t]{2}{*}{ Named After } & & & 0.0012 & 0.0075 & & & $0.0037 * *$ & -0.0068 \\
\hline & & & $(0.8617)$ & (1.1483) & & & $(-2.1318)$ & $(-0.7599)$ \\
\hline Observations & 2,913 & 2,913 & 5,878 & 5,878 & 5,582 & 5,582 & 5,818 & 5,818 \\
\hline R-squared & 0.0315 & 0.1212 & 0.0125 & 0.1204 & 0.0307 & 0.1327 & 0.0171 & 0.1181 \\
\hline Link Industry FE & Yes & Yes & Yes & Yes & Yes & Yes & Yes & Yes \\
\hline Year+Month+Day FE & Yes & Yes & Yes & Yes & Yes & Yes & Yes & Yes \\
\hline
\end{tabular}




\section{Table 4. Calendar Days Distance between Parent and Subsidiary Announcements}

The table reports the distribution of time distance (in calendar days) between a parent's earnings announcement and its subsidiary's in a given year. The sample is partitioned into (i) link-year observations where the parent and its subsidiary close their financial year on the same date and (ii) link-year observations where the parent and its subsidiaries do not. The samples are then further partitioned into these subsamples: (i) the parent and subsidiary make their earnings announcement on the same day, (ii) the subsidiary releases its earnings information first, and (iii) the parent releases its earnings first.

\begin{tabular}{lcccccc}
\hline & Nr. Obs. & Mean & Median & P25 & P75 & Std. \\
\hline Parent and Subsidiary & (with a Link) & with the Same Financial Year & & & \\
Same Day & 1,964 & 0 & 0 & 0 & 0 & 0 \\
Subsidiary First & 5,873 & 12.9 & 7 & 2 & 15 & 17.9 \\
Parent First & 4,613 & 22.7 & 14 & 28 & 6 & 28.4 \\
Parent and Subsidiary & (with a Link) & with a different Financial Year & & & \\
Same Day & 4 & 0 & 0 & 0 & 0 & 0 \\
Subsidiary First & 1,346 & 100.3 & 85 & 50 & 127 & 69.6 \\
Parent First & 1,051 & 140.7 & 118 & 196 & 85 & 79.6 \\
\hline
\end{tabular}

\section{Table 5. Parent and Subsidiary Announce on Same Day}

The table presents results from regressions of investor reactions to earnings announcements of earnings surprises (belonging to the top two quantiles of their distribution), for the cases where the parent and its subsidiary close their financial year on the same day and earnings announcements take place on the same day. Columns (1-4) report parent's investor reactions to the earnings announcements and columns (5-8) report subsidiary's investor reactions to the earnings announcements. Specifications in the even-numbered columns report results with industry fixed-effects. Parent controls are the parent's market value, the log of analyst coverage, the Tobin's $Q$, and a dummy variable equal to one if the firm's stock is illiquid. Subsidiary controls are the same as the parent's control (but applied to the subsidiary). Date fixed effects consists of year, month, and day-of- the-week fixed effects. Robust $\mathrm{t}$-statistics are reported between brackets. *,*, and $* * *$ indicate significance at the $10 \%, 5 \%$, and $1 \%$ level, respectively.

\begin{tabular}{|c|c|c|c|c|c|c|c|c|}
\hline \multirow{3}{*}{ Time window } & \multicolumn{4}{|c|}{ Parent's Investor Reaction } & \multicolumn{4}{|c|}{ Subsidiary's Investor Reactions } \\
\hline & \multicolumn{2}{|c|}{ BHAR $[0 ; 1]$} & \multicolumn{2}{|c|}{ BHAR $[2 ; 60]$} & \multicolumn{2}{|c|}{ BHAR $[0 ; 1]$} & \multicolumn{2}{|c|}{ BHAR $[2 ; 60]$} \\
\hline & (1) & (2) & (3) & (4) & (5) & (6) & (7) & $(8)$ \\
\hline Top Two Quantiles & $\begin{array}{c}0.0135 * * * \\
(2.9474)\end{array}$ & $\begin{array}{c}0.0149^{* * * *} \\
(3.0501)\end{array}$ & $\begin{array}{c}0.0105 \\
(0.6916)\end{array}$ & $\begin{array}{c}0.0065 \\
(0.4545)\end{array}$ & $\begin{array}{c}0.0163^{* * * *} \\
(3.6970)\end{array}$ & $\begin{array}{c}0.0141^{* * * *} \\
(3.5414)\end{array}$ & $\begin{array}{c}-0.0088 \\
(-0.5508)\end{array}$ & $\begin{array}{c}-0.0155 \\
(-1.2562)\end{array}$ \\
\hline Market Value & & $\begin{array}{c}0.0017 \\
(0.6359)\end{array}$ & & $\begin{array}{l}0.0138^{*} \\
(1.6877)\end{array}$ & & $\begin{array}{c}-0.0011 \\
(-0.4358)\end{array}$ & & $\begin{array}{c}0.0236^{* * * *} \\
(4.1229)\end{array}$ \\
\hline Q & & $\begin{array}{l}0.0032^{*} \\
(1.6935)\end{array}$ & & $\begin{array}{c}0.0028 \\
(0.3303)\end{array}$ & & $\begin{array}{c}0.0005 \\
(0.1140)\end{array}$ & & $\begin{array}{c}0.0111 \\
(0.7675)\end{array}$ \\
\hline Is Illiquid & & $\begin{array}{c}0.0077 \\
(0.9480)\end{array}$ & & $\begin{array}{c}-0.0058 \\
(-0.1075)\end{array}$ & & $\begin{array}{c}0.0121 \\
(1.1360)\end{array}$ & & $\begin{array}{c}-0.0334 \\
(-1.0447)\end{array}$ \\
\hline Nr. Analysts & & $\begin{array}{c}-0.0018 \\
(-0.7016)\end{array}$ & & $\begin{array}{l}-0.0168^{*} \\
(-1.8503)\end{array}$ & & $\begin{array}{c}0.0058 \\
(1.6151)\end{array}$ & & $\begin{array}{c}-0.0287 * * * * \\
(-3.0814)\end{array}$ \\
\hline Observations & 509 & 509 & 509 & 509 & 716 & 716 & 716 & 716 \\
\hline R-squared & 0.0719 & 0.0739 & 0.1122 & 0.1225 & 0.0546 & 0.0604 & 0.1400 & 0.1620 \\
\hline Firm Industry FE & No & Yes & No & Yes & No & Yes & No & Yes \\
\hline Year+Month+Day FE & Yes & Yes & Yes & Yes & Yes & Yes & Yes & Yes \\
\hline
\end{tabular}




\section{Table 6. Parent Announces First}

The table presents results from regressions of investors' reactions to earnings announcements of earnings surprises (belonging to the top two quantiles of their distribution) for the cases where the parent's and its subsidiary's financial years coincide and the parent releases its earnings prior to the subsidiary. Panel A reports the parent investor reactions to the announcement by the parent (columns 1-4), and to the subsidiary' announcement (columns 5-8). Panel B reports the subsidiary investor reaction to the parent's announcement (columns 1-4), and to the announcement of the subsidiary (columns 5-8). All specifications include year, month, and day-of-the-week fixed-effects. The even columns include firm controls and firm SIC-2 industry fixed effects for the models of investor reactions to their own company's announcement. If models test investors' reactions to the affiliated firm's announcement, the models include link industry (parent-subsidiary SIC-2) fixed effects, and link controls in addition to firm controls. Parent controls include the parent's market value, the log of analyst coverage, market-to-book ratio, and a dummy variable equals one if the stock is illiquid. We include similar controls for the subsidiary. Link controls comprise relative market value, percentage of control held by the parent, percentage of common analysts, a direct ownership dummy, dummy variables equal to one if parent and subsidiary are located in the same country, if they share part of a corporate name, and if a common institutional investor own a stake in the parent and the subsidiary, respectively. Robust t-stats are reported between brackets. $*, * *$, and $* * *$ indicate significance at the $10 \%, 5 \%$, and $1 \%$ level, respectively.

Panel A: Parent's Investor Reactions

Parent Investor Reactions

Parent's announcement

Subsidiary's announcement

\begin{tabular}{|c|c|c|c|c|c|c|c|c|}
\hline \multirow{3}{*}{ Time window } & & \\
\hline & \multicolumn{2}{|c|}{ BHAR $[0 ; 1]$} & \multicolumn{2}{|c|}{ BHAR $[2 ; 60]$} & \multicolumn{2}{|c|}{$\operatorname{BHAR}[0 ; 1]$} & \multicolumn{2}{|c|}{ BHAR $[2 ; 60]$} \\
\hline & (1) & (2) & (3) & (4) & (5) & (6) & (7) & (8) \\
\hline \multirow[t]{2}{*}{ Top Two Quantiles } & $0.0096^{* *}$ & $0.0079 * *$ & -0.0065 & -0.0149 & $0.0032 * *$ & $0.0046^{* *}$ & -0.0049 & -0.0097 \\
\hline & $(2.3817)$ & $(2.3073)$ & $(-0.4825)$ & $(-1.0902)$ & (2.1844) & $(2.3713)$ & $(-0.7409)$ & $(-1.1692)$ \\
\hline \multirow[t]{2}{*}{ Market Value } & & -0.0023 & & 0.0077 & & $-0.0029 * * *$ & & $0.0087 * *$ \\
\hline & & $(-1.0492)$ & & $(1.2030)$ & & $(-2.9091)$ & & (2.1379) \\
\hline \multirow[t]{2}{*}{ Q } & & 0.0013 & & $0.0754 * * *$ & & $0.0048 * * *$ & & $0.0220 * * *$ \\
\hline & & $(0.3317)$ & & $(3.8671)$ & & (3.9271) & & $(2.8229)$ \\
\hline \multirow[t]{2}{*}{ Is Illiquid } & & -0.0085 & & -0.0321 & & -0.0010 & & $-0.1172 * * *$ \\
\hline & & $(-1.0925)$ & & $(-0.8329)$ & & $(-0.1991)$ & & $(-5.2685)$ \\
\hline \multirow[t]{2}{*}{ Nr. Analysts } & & -0.0009 & & -0.0012 & & $0.0028^{*}$ & & $-0.0142 *$ \\
\hline & & $(-0.3323)$ & & $(-0.1338)$ & & (1.7243) & & $(-1.9575)$ \\
\hline \multirow[t]{2}{*}{$\%$ Common Analysts } & & & & & & 0.0138 & & $0.1089^{*}$ \\
\hline & & & & & & $(0.7779)$ & & $(1.7849)$ \\
\hline \multirow[t]{2}{*}{ Relative Market Value } & & & & & & 0.0007 & & 0.0100 \\
\hline & & & & & & $(0.2535)$ & & $(1.0175)$ \\
\hline \multirow[t]{2}{*}{ \% Ownership } & & & & & & 0.0000 & & 0.0001 \\
\hline & & & & & & $(0.5545)$ & & $(0.4548)$ \\
\hline \multirow[t]{2}{*}{ Has a Common Owner } & & & & & & 0.0008 & & 0.0069 \\
\hline & & & & & & $(0.3362)$ & & $(0.6176)$ \\
\hline \multirow[t]{2}{*}{ Directly Owned } & & & & & & 0.0012 & & 0.0013 \\
\hline & & & & & & $(0.6742)$ & & $(0.1310)$ \\
\hline \multirow[t]{2}{*}{ Same Country } & & & & & & -0.0011 & & -0.0125 \\
\hline & & & & & & $(-0.5512)$ & & $(-1.0207)$ \\
\hline \multirow[t]{2}{*}{ Named After } & & & & & & 0.0017 & & -0.0113 \\
\hline & & & & & & $(0.8326)$ & & $(-1.0605)$ \\
\hline Observations & 748 & 748 & 748 & 748 & 2,003 & 2,003 & 2,003 & 2,003 \\
\hline R-squared & 0.0502 & 0.0533 & 0.1435 & 0.1800 & 0.0215 & 0.0349 & 0.1053 & 0.1385 \\
\hline Firm Industry FE & No & Yes & No & Yes & No & No & No & No \\
\hline Link Industry FE & No & No & No & No & No & Yes & No & Yes \\
\hline Year+Month+Day FE & Yes & Yes & Yes & Yes & Yes & Yes & Yes & Yes \\
\hline
\end{tabular}




\section{Table 6. Parent Announces First (Cont'd)}

Panel B: Subsidiary's Investor Reactions

\begin{tabular}{|c|c|c|c|c|c|c|c|c|}
\hline \multirow{4}{*}{ Time window } & \multicolumn{8}{|c|}{ Subsidiary Investor Reactions } \\
\hline & \multicolumn{4}{|c|}{ Parent's announcement } & \multicolumn{4}{|c|}{ Subsidiary's announcement } \\
\hline & \multicolumn{2}{|c|}{ BHAR $[0 ; 1]$} & \multicolumn{2}{|c|}{ BHAR[2;60] } & \multicolumn{2}{|c|}{ BHAR $[0 ; 1]$} & \multicolumn{2}{|c|}{ BHAR $[2 ; 60]$} \\
\hline & (1) & $(2)$ & (3) & (4) & (5) & $(6)$ & (7) & $(8)$ \\
\hline Top Two Quantiles & $\begin{array}{c}0.0000 \\
(0.0048)\end{array}$ & $\begin{array}{c}-0.0010 \\
(-0.3883)\end{array}$ & $\begin{array}{c}0.0036 \\
(0.3625)\end{array}$ & $\begin{array}{c}-0.0044 \\
(-0.4244)\end{array}$ & $\begin{array}{c}0.0148 * * * \\
(4.2682)\end{array}$ & $\begin{array}{c}0.0147 * * * \\
(4.9690)\end{array}$ & $\begin{array}{c}0.0305 * * * \\
(3.0210)\end{array}$ & $\begin{array}{c}0.0160 \\
(1.4046)\end{array}$ \\
\hline Market Value & & $\begin{array}{c}0.0010 \\
(0.4977)\end{array}$ & & $\begin{array}{c}0.0214 * * * \\
(3.8763)\end{array}$ & & $\begin{array}{c}0.0013 \\
(0.6803)\end{array}$ & & $\begin{array}{c}0.0171 * * * \\
(3.7117)\end{array}$ \\
\hline Q & & $\begin{array}{c}0.0016 \\
(1.2480)\end{array}$ & & $\begin{array}{c}0.0099 \\
(1.4053)\end{array}$ & & $\begin{array}{c}0.0034 \\
(1.1916)\end{array}$ & & $\begin{array}{l}0.0130 * \\
(1.7204)\end{array}$ \\
\hline Is Illiquid & & $\begin{array}{l}-0.0138 * \\
(-1.9242)\end{array}$ & & $\begin{array}{c}-0.0512 \\
(-1.5112)\end{array}$ & & $\begin{array}{c}-0.0046 \\
(-0.9158)\end{array}$ & & $\begin{array}{c}-0.0662 * * * \\
(-2.7175)\end{array}$ \\
\hline Nr. Analysts & & $\begin{array}{c}-0.0018 \\
(-0.8553)\end{array}$ & & $\begin{array}{l}-0.0142 * \\
(-1.9090)\end{array}$ & & $\begin{array}{c}-0.0008 \\
(-0.3377)\end{array}$ & & $\begin{array}{c}-0.0134 * * \\
(-2.0593)\end{array}$ \\
\hline$\%$ Common Analysts & & $\begin{array}{c}0.0070 \\
(0.3693)\end{array}$ & & $\begin{array}{c}0.0399 \\
(0.5946)\end{array}$ & & & & \\
\hline Relative Market Value & & $\begin{array}{c}0.0041 \\
(1.2393)\end{array}$ & & $\begin{array}{c}-0.0066 \\
(-0.5386)\end{array}$ & & & & \\
\hline$\%$ Ownership & & $\begin{array}{c}0.0001 \\
(0.9463)\end{array}$ & & $\begin{array}{c}0.0001 \\
(0.2292)\end{array}$ & & & & \\
\hline Has a Common Owner & & $\begin{array}{c}-0.0035 \\
(-1.0029)\end{array}$ & & $\begin{array}{c}0.0119 \\
(0.6318)\end{array}$ & & & & \\
\hline Directly Owned & & $\begin{array}{c}0.0024 \\
(0.5445)\end{array}$ & & $\begin{array}{c}-0.0051 \\
(-0.2915)\end{array}$ & & & & \\
\hline Same Country & & $\begin{array}{c}-0.0047 \\
(-1.2733)\end{array}$ & & $\begin{array}{c}0.0288 \\
(1.5228)\end{array}$ & & & & \\
\hline Named After & & $\begin{array}{c}-0.0068 * * \\
(-2.0603)\end{array}$ & & $\begin{array}{c}-0.0111 \\
(-0.7691)\end{array}$ & & & & \\
\hline Observations & 1,669 & 1,669 & 1,669 & 1,669 & 1,878 & 1,878 & 1,878 & 1,878 \\
\hline R-squared & 0.0417 & 0.0522 & 0.1475 & 0.1872 & 0.0353 & 0.0376 & 0.1259 & 0.1462 \\
\hline Link Controls & No & Yes & No & Yes & No & No & No & No \\
\hline Link Industry FE & No & Yes & No & Yes & No & No & No & No \\
\hline Year+Month+Day FE & Yes & Yes & Yes & Yes & Yes & Yes & Yes & Yes \\
\hline
\end{tabular}


Table 7. Subsidiary Announces First

The table presents results from regressions of investors' reactions to earnings announcement of earnings surprises (belonging to the top two quantiles of their distribution), for the cases where parent and subsidiary close their financial year on the same date and where the subsidiary releases its earnings first. Panel A reports the parent company's reactions to the subsidiary's announcement (columns 1-4), and to the announcement of the parent which takes place after the subsidiary's (columns 5-8). Panel B reports the subsidiary's investor reactions to the subsidiary's announcement (columns 1-4), and to the parent's announcement (columns 5-8). All specifications report results with year, month, and day-of-the-week fixed-effects. The even-numbered columns include firm controls and firm SIC-2 industry fixed effects, if they concern investor's reactions to their own company's announcement. If models test investors reaction to the affiliated company's announcement, models include link industry (parent-subsidiary SIC-2) fixed effects and parent-subsidiary controls in addition to firm controls. Parent controls comprise the parent's market value, $\log$ of analyst coverage, the Tobin's $\mathrm{Q}$, and an illiquidity dummy. We include similar controls for the subsidiary. Link controls comprise relative value, percentage of control held by the parent, percentage of common analysts, a directly ownership dummy, dummy variables equal to one if parent and subsidiary are located in the same country, share (part of) a corporate name, and if they share a common institutional owner, respectively. Robust t-stats are reported between brackets. $*, * *$, and $* * *$ indicate significance at the $10 \%, 5 \%$, and $1 \%$ level, respectively.

\section{Panel A: Parent's Investor Reactions}

Parent's Investor Reactions

Subsidiary's announcement

Parent's announcement

\begin{tabular}{|c|c|c|c|c|c|c|c|c|}
\hline \multirow[t]{2}{*}{ Time window } & \multicolumn{2}{|c|}{ BHAR $[0 ; 1]$} & \multicolumn{2}{|c|}{ BHAR[2;60] } & \multicolumn{2}{|c|}{$\operatorname{BHAR}[0 ; 1]$} & \multicolumn{2}{|c|}{ BHAR[2;60] } \\
\hline & $(1)$ & (2) & (3) & (4) & $(5)$ & $(6)$ & $(7)$ & $(8)$ \\
\hline Top Two Quantiles & $\begin{array}{c}0.0037 * * \\
(2.5551)\end{array}$ & $\begin{array}{l}0.0032 * \\
(1.8337)\end{array}$ & $\begin{array}{c}0.0292 * * * \\
(3.8552)\end{array}$ & $\begin{array}{c}0.0278 * * * \\
(3.5360)\end{array}$ & $\begin{array}{c}0.0124 * * * \\
(4.5370)\end{array}$ & $\begin{array}{c}0.0106^{* * * *} \\
(3.2325)\end{array}$ & $\begin{array}{c}0.0203 * * \\
(1.9883)\end{array}$ & $\begin{array}{l}0.0196 * \\
(1.9305)\end{array}$ \\
\hline Market Value & & $\begin{array}{c}0.0001 \\
(0.1293)\end{array}$ & & $\begin{array}{c}0.0114 * * * \\
(2.7642)\end{array}$ & & $\begin{array}{l}0.0015 * \\
(1.8092)\end{array}$ & & $\begin{array}{c}0.0113 * * * \\
(2.8550)\end{array}$ \\
\hline Q & & $\begin{array}{c}0.0020 \\
(1.5619)\end{array}$ & & $\begin{array}{c}0.0119 \\
(0.9496)\end{array}$ & & $\begin{array}{c}0.0014 \\
(0.5668)\end{array}$ & & $\begin{array}{c}0.0094 \\
(0.9027)\end{array}$ \\
\hline Is Illiquid & & $\begin{array}{l}-0.0096^{*} \\
(-1.8830)\end{array}$ & & $\begin{array}{c}-0.0988 * * * \\
(-3.6244)\end{array}$ & & $\begin{array}{c}-0.0045 \\
(-0.8320)\end{array}$ & & $\begin{array}{c}-0.0650 * * * \\
(-3.1141)\end{array}$ \\
\hline Nr. Analysts & & $\begin{array}{l}-0.0027 * \\
(-1.8801)\end{array}$ & & $\begin{array}{c}-0.0335 * * * \\
(-6.1819)\end{array}$ & & $\begin{array}{c}-0.0010 \\
(-0.5729)\end{array}$ & & $\begin{array}{c}-0.0195 * * * \\
(-3.6037)\end{array}$ \\
\hline$\%$ Common Analysts & & $\begin{array}{c}-0.0255 * * * \\
(-2.6902)\end{array}$ & & $\begin{array}{c}-0.0659 \\
(-0.9897)\end{array}$ & & & & \\
\hline Relative Market Value & & $\begin{array}{c}0.0012 \\
(0.7340)\end{array}$ & & $\begin{array}{c}0.0027 \\
(0.3148)\end{array}$ & & & & \\
\hline$\%$ Ownership & & $\begin{array}{c}0.0000 \\
(0.7128)\end{array}$ & & $\begin{array}{c}-0.0002 \\
(-0.7339)\end{array}$ & & & & \\
\hline Has a Common Owner & & $\begin{array}{c}-0.0032 \\
(-1.0481)\end{array}$ & & $\begin{array}{c}0.0170 \\
(1.4222)\end{array}$ & & & & \\
\hline Directly Owned & & $\begin{array}{c}-0.0022 \\
(-0.7074)\end{array}$ & & $\begin{array}{c}-0.0241 \\
(-1.5474)\end{array}$ & & & & \\
\hline Same Country & & $\begin{array}{l}-0.0038 * \\
(-1.7902)\end{array}$ & & $\begin{array}{c}0.0379 * * * \\
(2.6894)\end{array}$ & & & & \\
\hline Named After & & $\begin{array}{c}0.0021 \\
(0.8380)\end{array}$ & & $\begin{array}{c}0.0119 \\
(1.4685)\end{array}$ & & & & \\
\hline Observations & 2,229 & 2,229 & 2,229 & 2,229 & 1,236 & 1,236 & 1,236 & 1,236 \\
\hline R-squared & 0.0249 & 0.0422 & 0.1363 & 0.1786 & 0.0389 & 0.0371 & 0.1576 & 0.1770 \\
\hline Link Controls & No & Yes & No & Yes & No & No & No & No \\
\hline Link Industry FE & No & Yes & No & Yes & No & No & No & No \\
\hline Year+Month+Day FE & Yes & Yes & Yes & Yes & Yes & Yes & Yes & Yes \\
\hline
\end{tabular}




\section{Table 7. Subsidiary Announces First (Cont'd)}

Panel B: Subsidiary's Investor Reactions

\begin{tabular}{|c|c|c|c|c|c|c|c|c|}
\hline \multirow{4}{*}{ Time window } & \multicolumn{8}{|c|}{ Subsidiary's Investor Reactions } \\
\hline & \multicolumn{4}{|c|}{ Subsidiary's announcement } & \multicolumn{4}{|c|}{ Parent's announcement } \\
\hline & \multicolumn{2}{|c|}{ BHAR $[0 ; 1]$} & \multicolumn{2}{|c|}{ BHAR $[2 ; 60]$} & \multicolumn{2}{|c|}{ BHAR $[0 ; 1]$} & \multicolumn{2}{|c|}{ BHAR $[2 ; 60]$} \\
\hline & (1) & (2) & (3) & (4) & (5) & (6) & (7) & (8) \\
\hline Top Two Quantiles & $\begin{array}{c}0.0212 * * * \\
(7.8189)\end{array}$ & $\begin{array}{c}0.0196^{* * * *} \\
(6.2674)\end{array}$ & $\begin{array}{c}0.0301 * * * \\
(3.2568)\end{array}$ & $\begin{array}{c}0.0309 * * * \\
(2.9738)\end{array}$ & $\begin{array}{c}0.0007 \\
(0.3184)\end{array}$ & $\begin{array}{c}-0.0003 \\
(-0.1323)\end{array}$ & $\begin{array}{l}0.0150 * \\
(1.8922)\end{array}$ & $\begin{array}{c}0.0162 \\
(1.6446)\end{array}$ \\
\hline Market Value & & $\begin{array}{c}0.0026 * * \\
(2.3326)\end{array}$ & & $\begin{array}{c}0.0130 * * \\
(2.4874)\end{array}$ & & $\begin{array}{c}-0.0004 \\
(-0.3571)\end{array}$ & & $\begin{array}{l}0.0142 * * \\
(2.4915)\end{array}$ \\
\hline Q & & $\begin{array}{c}0.0023 \\
(0.8925)\end{array}$ & & $\begin{array}{c}0.0249 * * * \\
(2.9691)\end{array}$ & & $\begin{array}{c}0.0012 \\
(0.8852)\end{array}$ & & $\begin{array}{c}0.0196 * * * \\
(3.8718)\end{array}$ \\
\hline Is Illiquid & & $\begin{array}{c}-0.0011 \\
(-0.2274)\end{array}$ & & $\begin{array}{c}-0.0578 * * \\
(-2.4199)\end{array}$ & & $\begin{array}{c}-0.0090 \\
(-0.7403)\end{array}$ & & $\begin{array}{c}-0.0235 \\
(-0.5637)\end{array}$ \\
\hline Nr. Analysts & & $\begin{array}{c}-0.0017 \\
(-1.2190)\end{array}$ & & $\begin{array}{c}-0.0227 * * * \\
(-2.7390)\end{array}$ & & $\begin{array}{c}0.0011 \\
(0.8467)\end{array}$ & & $\begin{array}{c}-0.0200 * * * \\
(-2.6055)\end{array}$ \\
\hline$\%$ Common Analysts & & & & & & $\begin{array}{c}-0.0049 \\
(-0.2278)\end{array}$ & & $\begin{array}{c}-0.0098 \\
(-0.1380)\end{array}$ \\
\hline Relative Market Value & & & & & & $\begin{array}{c}-0.0004 \\
(-0.2613)\end{array}$ & & $\begin{array}{l}-0.0098^{*} \\
(-1.6787)\end{array}$ \\
\hline$\%$ Ownership & & & & & & $\begin{array}{c}-0.0000 \\
(-0.4884)\end{array}$ & & $\begin{array}{c}0.0001 \\
(0.3325)\end{array}$ \\
\hline Has a Common Owner & & & & & & $\begin{array}{c}-0.0007 \\
(-0.1984)\end{array}$ & & $\begin{array}{c}0.0069 \\
(0.4074)\end{array}$ \\
\hline Directly Owned & & & & & & $\begin{array}{c}0.0036 \\
(1.1135)\end{array}$ & & $\begin{array}{c}-0.0160 \\
(-1.1222)\end{array}$ \\
\hline Same Country & & & & & & $\begin{array}{c}0.0053 \\
(1.3991)\end{array}$ & & $\begin{array}{c}0.0192 \\
(1.3016)\end{array}$ \\
\hline Named After & & & & & & $\begin{array}{c}-0.0028 \\
(-1.3613)\end{array}$ & & $\begin{array}{c}-0.0152 \\
(-1.0308)\end{array}$ \\
\hline Observations & 2,125 & 2,125 & 2,125 & 2,125 & 2,541 & 2,541 & 2,541 & 2,541 \\
\hline R-squared & 0.0526 & 0.0525 & 0.1224 & 0.1494 & 0.0152 & 0.0183 & 0.1230 & 0.1419 \\
\hline Link Controls & No & No & No & No & No & Yes & No & Yes \\
\hline Link Industry FE & No & No & No & No & No & Yes & No & Yes \\
\hline Year+Month+Day FE & Yes & Yes & Yes & Yes & Yes & Yes & Yes & Yes \\
\hline
\end{tabular}




\section{Table 8. Channels of Parent Investor Unawareness}

The table presents results from regressions of parent investor reactions to subsidiary's earnings announcement, for the cases where parent and subsidiary close their financial year on the same date and where the subsidiary releases its earnings first. Panel A reports immediate and delayed reactions to subsidiary's announcement when the parent and subsidiary are located in the same country (columns 1-2) and when they are located in different countries (columns 3-4). Panel B reports immediate and delayed reactions to subsidiary's announcement when the subsidiary is directly owned by the parent (columns 1-2) and when subsidiary is indirectly controlled by the parent (columns 3-4). Panel C reports the parent reaction to subsidiary's announcement when the parent and its subsidiary share part of a corporate name (columns 1-2), and when the parent and its subsidiary have or do not have an institutional outside investor in common (columns 3-4). Panel D reports the parent reaction to the subsidiary's announcement when the parent controls less (more) than 50\% of the subsidiary (columns 1-2), and when the subsidiary's relative market value is higher (lower) than the median of the relative market value distribution (columns 3-4). All specifications include year, month, day-of-theweek fixed-effects, link (parent-subsidiary SIC-2) fixed effects, parent companies, and link controls. Parent controls comprise the parent's market value, log of analyst coverage, the Tobin's Q, and an illiquidity dummy. Link controls include relative market value, percentage of control held by the parent, percentage of common analysts, a directly ownership dummy, dummy variables equal to one if parent and subsidiary are located in the same country, operate in the same SIC-2 industry, if they share part of a corporate name, and if they share a common institutional owner, respectively. Robust t-stats are reported between brackets. *,**, and *** indicate significance at the 10\%, 5\%, and $1 \%$ level, respectively.

\begin{tabular}{|c|c|c|c|c|}
\hline \multirow{3}{*}{ Panel A } & (1) & (2) & (3) & (4) \\
\hline & \multicolumn{2}{|c|}{ Same Country } & \multicolumn{2}{|c|}{ Different Country } \\
\hline & $\operatorname{BHAR}[0 ; 1]$ & BHAR $[2 ; 60]$ & $\operatorname{BHAR}[0 ; 1]$ & BHAR $[2 ; 60]$ \\
\hline Top Two Quantiles & $\begin{array}{c}0.0045^{* *} \\
(2.1071)\end{array}$ & $\begin{array}{c}0.0285^{* * *} * \\
(3.2147)\end{array}$ & $\begin{array}{c}0.0012 \\
(0.4171)\end{array}$ & $\begin{array}{c}0.0303 * \\
(1.9108)\end{array}$ \\
\hline \multirow[t]{2}{*}{ Panel B } & \multicolumn{2}{|c|}{ Directly Owned } & \multicolumn{2}{|c|}{ Indirectly Owned } \\
\hline & BHAR $[0 ; 1]$ & BHAR $[2 ; 60]$ & $\operatorname{BHAR}[0 ; 1]$ & BHAR $[2 ; 60]$ \\
\hline Top Two Quantiles & $\begin{array}{c}0.0042 * * \\
(1.9937)\end{array}$ & $\begin{array}{c}0.0253 * * * \\
(2.6614)\end{array}$ & $\begin{array}{c}0.0032 \\
(0.9161)\end{array}$ & $\begin{array}{c}0.0324 * * \\
(2.2234)\end{array}$ \\
\hline \multirow[t]{2}{*}{ Panel C } & \multicolumn{2}{|c|}{ Different Name } & \multicolumn{2}{|c|}{ Named After } \\
\hline & BHAR $[0 ; 1]$ & BHAR $[2 ; 60]$ & BHAR $[0 ; 1]$ & BHAR $[2 ; 60]$ \\
\hline Top Two Quantiles & $\begin{array}{c}0.0029 \\
(1.4991)\end{array}$ & $\begin{array}{c}0.0208 * * \\
(2.0753)\end{array}$ & $\begin{array}{c}0.0052 \\
(1.4188)\end{array}$ & $\begin{array}{c}0.0306^{* *} \\
(2.2150)\end{array}$ \\
\hline \multirow[t]{3}{*}{ Panel D } & \multicolumn{2}{|c|}{$\%$ Ownership } & \multicolumn{2}{|c|}{ Relative Size } \\
\hline & $<50 \%$ & $>50 \%$ & $<$ Median & $>$ Median \\
\hline & \multicolumn{4}{|c|}{ BHAR $[0 ; 60]$} \\
\hline Top Two Quantiles & $\begin{array}{c}0.0265 * * \\
(2.1429)\end{array}$ & $\begin{array}{c}0.0343 * * \\
(2.5236)\end{array}$ & $\begin{array}{l}0.0188^{*} \\
(1.7739)\end{array}$ & $\begin{array}{c}0.0337 * * * \\
(2.6387)\end{array}$ \\
\hline \multicolumn{5}{|c|}{ Included in each above model: } \\
\hline Firm Controls & Yes & Yes & Yes & Yes \\
\hline Link Controls & Yes & Yes & Yes & Yes \\
\hline Link Industry FE & Yes & Yes & Yes & Yes \\
\hline Year+Month+Day FE & Yes & Yes & Yes & Yes \\
\hline
\end{tabular}




\section{Table 9. Parent Investor Sophistication}

The table presents results from regressions of parent company investor reactions to subsidiary's earnings announcement, for the cases where parent and subsidiary close their financial year on the same date and where the subsidiary releases earnings first. Columns (1-2) report the parent's immediate and delayed reactions when at least one institutional investor owns a stake (of $\max , 10 \%$ ) in the parent. Columns (3-4) report the parent's immediate and delayed reactions when no institutional investor owns equity in the parent. Columns (5-6) report the parent's total reaction to subsidiary's announcement when the sum of stakes owned by institutional investors represent more than 5\% and more than $10 \%$ of parent's shares, respectively. Columns (5-6) report the parent's share price reaction to its subsidiary's announcement when the parent and subsidiary have a common institutional owner in a given year. All specifications report results with year, month, day-of-the-week fixed-effects, link (parent-subsidiary SIC-2) fixed effects, parent companies, and link controls. Parent controls comprise the parent's market value, log of analyst coverage, the Tobin's Q, and an illiquidity dummy. Link controls include relative market value, percentage of control held by the parent, percentage of common analysts, a directly ownership dummy, dummy variables equal to one if parent and subsidiary are located in the same country, operate in the same SIC-2 industry, share (part of) a corporate name, and if they share a common institutional owner, respectively. Robust t-stats are reported between brackets. *, **, and $* * *$ indicate significance at the $10 \%, 5 \%$, and $1 \%$ level, respectively.

\begin{tabular}{|c|c|c|c|c|c|c|c|c|}
\hline & \multicolumn{4}{|c|}{ Has an Institutional Owner } & \multicolumn{2}{|c|}{$\begin{array}{c}\text { \% Institutional } \\
\text { Ownership }\end{array}$} & \multicolumn{2}{|c|}{ Has Common Owner } \\
\hline & \multicolumn{2}{|c|}{ Yes } & \multicolumn{2}{|c|}{ No } & \multirow{3}{*}{$\begin{array}{c}>5 \% \\
{[0 ; 60]} \\
(5) \\
\end{array}$} & \multirow{3}{*}{$\begin{array}{c}>10 \% \\
{[0 ; 60]} \\
(6)\end{array}$} & \multirow{3}{*}{$\begin{array}{c}\text { Yes } \\
{[0 ; 60]} \\
(7)\end{array}$} & \multirow{3}{*}{$\begin{array}{c}\text { No } \\
{[0 ; 60]} \\
(8) \\
\end{array}$} \\
\hline & {$[0 ; 1]$} & {$[2 ; 60]$} & {$[0 ; 1]$} & {$[2 ; 60]$} & & & & \\
\hline & (1) & (2) & (3) & (4) & & & & \\
\hline Top Two Quantiles & $\begin{array}{l}0.0044^{*} \\
(1.7837)\end{array}$ & $\begin{array}{c}0.0350 * * * \\
(3.0001)\end{array}$ & $\begin{array}{c}0.0032 \\
(1.3046)\end{array}$ & $\begin{array}{l}0.0226^{*} \\
(1.8459)\end{array}$ & $\begin{array}{c}0.0271 * * \\
(2.0763)\end{array}$ & $\begin{array}{c}0.0326 * * \\
(2.1814)\end{array}$ & $\begin{array}{c}0.0344 * * \\
(2.4987)\end{array}$ & $\begin{array}{c}0.0287 * * * \\
(2.6601)\end{array}$ \\
\hline Observations & 1,234 & 1,234 & 995 & 995 & 1,057 & 911 & 954 & 1,275 \\
\hline R-squared & 0.0685 & 0.2452 & 0.0854 & 0.1906 & 0.2433 & 0.2650 & 0.2594 & 0.1829 \\
\hline Firm Controls & Yes & Yes & Yes & Yes & Yes & Yes & Yes & Yes \\
\hline Link Controls & Yes & Yes & Yes & Yes & Yes & Yes & Yes & Yes \\
\hline Link Industry FE & Yes & Yes & Yes & Yes & Yes & Yes & Yes & Yes \\
\hline Year+Month+Day FE & Yes & Yes & Yes & Yes & Yes & Yes & Yes & Yes \\
\hline
\end{tabular}




\section{Table 10. Strategic Announcement Timing and Investor Reactions}

The table tests the strategic disclosure hypothesis: The models in columns (1-4) report results of investor reactions to earnings announcements while endogenizing the parent's and subsidiary's decision about when to announce (both announce on same day versus on different days). First stage specifications include dummy variables Surprise Both Top Two and Surprise Both Bottom Two, which are equal to one if both parent's and subsidiary's earnings surprises are in the top (bottom) two quantiles of their respective distributions, and zero otherwise. Columns (1) and (3) report the first stage results of parent's and subsidiary's announcement timing, respectively. The model in columns (5-7) estimates the parent's investor immediate (column (6)) and longer-term (column (7)) reactions to the subsidiary's announcement conditional on the subsidiary announcing first (relative to the parent announcing first). The subsidiary's investor reactions to parent announcements are not reported. First stage specifications include link industry fixed effects and time fixed effects. Second stage specifications include link industry fixed effects, year, month and day-of-the-week fixed effects. Note that link industry fixed effects in this table are based on the Bureau van Dijk 1-digit industry classification. Robust t-tats are between brackets. *, **, and *** indicate significance at $10 \%, 5 \%$, and $1 \%$, respectively.

\begin{tabular}{|c|c|c|c|c|c|c|c|}
\hline \multirow[b]{2}{*}{ Time window } & \multicolumn{2}{|c|}{$\begin{array}{c}\text { P \& S Announce on Same } \\
\text { vs Different Day } \\
\text { P' Investors }\end{array}$} & \multicolumn{2}{|c|}{$\begin{array}{c}\text { P \& S Announce on Same } \\
\text { vs Different } \\
\text { S' Investors }\end{array}$} & \multicolumn{3}{|c|}{$\begin{array}{c}\text { S Announces First versus Last } \\
\text { P' Investor Reactions at S' } \\
\text { Announcement }\end{array}$} \\
\hline & $\begin{array}{l}\text { 1st Stage } \\
\text { Same Day } \\
\text { (1) }\end{array}$ & $\begin{array}{l}\text { 2nd Stage } \\
{[0 ; 1]} \\
(2)\end{array}$ & $\begin{array}{c}\text { 1st Stage } \\
\text { Same Day } \\
\text { (3) }\end{array}$ & $\begin{array}{l}\text { 2nd Stage } \\
\qquad 0 ; 1] \\
(4)\end{array}$ & $\begin{array}{l}\text { 1st Stage } \\
\text { S. First } \\
(5)\end{array}$ & $\begin{array}{l}\text { 2nd Stage } \\
\qquad[0 ; 1] \\
(6)\end{array}$ & $\begin{array}{c}\text { 2nd Stage } \\
{[2 ; 60]} \\
(7)\end{array}$ \\
\hline Top Two Quantiles & & $\begin{array}{c}0.0127 * * * \\
(4.6261)\end{array}$ & & $\begin{array}{c}0.0201 * * * \\
(7.5355)\end{array}$ & & $\begin{array}{c}0.0037 * * \\
(2.5098)\end{array}$ & $\begin{array}{c}0.0315 * * * \\
(4.2371)\end{array}$ \\
\hline Market Value & & $\begin{array}{c}0.0008 \\
(0.6156)\end{array}$ & & $\begin{array}{c}-0.0005 \\
(-0.3872)\end{array}$ & & $\begin{array}{c}0.0004 \\
(0.6144) \\
- \\
0.0104 * *\end{array}$ & $\begin{array}{c}0.0108 * * * \\
(3.2023)\end{array}$ \\
\hline Is Illiquid & & $\begin{array}{c}-0.0058 \\
(-0.9249)\end{array}$ & & $\begin{array}{l}-0.0129 * \\
(-1.9063)\end{array}$ & & $\begin{array}{c}* \\
(-2.8437)\end{array}$ & $\begin{array}{c}-0.0999 * * * \\
(-5.4515)\end{array}$ \\
\hline Nr. Analysts & & $\begin{array}{c}0.0003 \\
(0.1489)\end{array}$ & & $\begin{array}{l}0.0032 * \\
(1.7020)\end{array}$ & & $\begin{array}{c}-0.0017 \\
(-1.5610)\end{array}$ & $\begin{array}{c}-0.0274 * * * \\
(-5.1834)\end{array}$ \\
\hline Relative Market Value & $\begin{array}{c}0.3842 * * * \\
(11.2342)\end{array}$ & $\begin{array}{c}-0.0018 \\
(-0.8424)\end{array}$ & $\begin{array}{c}0.1998 * * * \\
(6.2964)\end{array}$ & $\begin{array}{l}0.0043 * \\
(1.7612)\end{array}$ & $\begin{array}{c}0.2033 * * * \\
(6.6844)\end{array}$ & $\begin{array}{l}0.0023 * \\
(1.6671)\end{array}$ & $\begin{array}{c}0.0035 \\
(0.5098)\end{array}$ \\
\hline Has a Common Owner & $\begin{array}{c}0.0147 \\
(0.1897)\end{array}$ & $\begin{array}{c}0.0015 \\
(0.3435)\end{array}$ & $\begin{array}{c}-0.1209 * * \\
(-2.1057)\end{array}$ & $\begin{array}{c}0.0012 \\
(0.2740)\end{array}$ & $\begin{array}{c}-0.1244 * * \\
(-2.2562)\end{array}$ & $\begin{array}{c}0.0021 \\
(0.8456)\end{array}$ & $\begin{array}{c}0.0028 \\
(0.2253)\end{array}$ \\
\hline$\%$ Ownership & $\begin{array}{c}0.0002 \\
(0.2002)\end{array}$ & $\begin{array}{c}-0.0001 \\
(-0.8194)\end{array}$ & $\begin{array}{c}0.0037 * * * \\
(4.2812)\end{array}$ & $\begin{array}{c}0.0000 \\
(0.1771)\end{array}$ & $\begin{array}{c}0.0041 * * * \\
(4.8500)\end{array}$ & $\begin{array}{c}0.0001 \\
(1.6151)\end{array}$ & $\begin{array}{c}-0.0002 \\
(-1.0036)\end{array}$ \\
\hline Directly Owned & $\begin{array}{c}0.0826 \\
(1.2910)\end{array}$ & $\begin{array}{c}0.0018 \\
(0.4771)\end{array}$ & $\begin{array}{c}0.1571 * * * \\
(3.2990)\end{array}$ & $\begin{array}{l}0.0067 * \\
(1.7978)\end{array}$ & $\begin{array}{c}0.1488 * * * \\
(3.2148)\end{array}$ & $\begin{array}{c}-0.0022 \\
(-1.0702)\end{array}$ & $\begin{array}{c}-0.0230 * * \\
(-2.1858)\end{array}$ \\
\hline Same Industry & $\begin{array}{c}-0.0644 \\
(-0.7638)\end{array}$ & $\begin{array}{c}0.0030 \\
(0.6950)\end{array}$ & $\begin{array}{c}-0.1927 * * * \\
(-3.2091)\end{array}$ & $\begin{array}{c}-0.0037 \\
(-0.8950)\end{array}$ & $\begin{array}{c}-0.1822 * * * \\
(-3.1240)\end{array}$ & $\begin{array}{c}-0.0038 \\
(-1.6203)\end{array}$ & $\begin{array}{c}-0.0184 \\
(-1.5720)\end{array}$ \\
\hline Same Country & $\begin{array}{c}0.1880 * * * \\
(2.8386)\end{array}$ & $\begin{array}{c}0.0017 \\
(0.4131)\end{array}$ & $\begin{array}{c}0.1446 * * * \\
(2.9499)\end{array}$ & $\begin{array}{c}0.0030 \\
(0.7593)\end{array}$ & $\begin{array}{c}0.1351 * * * \\
(2.8482)\end{array}$ & $\begin{array}{c}-0.0023 \\
(-1.0451)\end{array}$ & $\begin{array}{c}0.0473 * * * \\
(4.2594)\end{array}$ \\
\hline Named After & $\begin{array}{c}0.5168 * * * \\
(8.5714)\end{array}$ & $\begin{array}{c}0.0005 \\
(0.1385)\end{array}$ & $\begin{array}{c}0.4027 * * * \\
(9.6158)\end{array}$ & $\begin{array}{c}-0.0016 \\
(-0.4517)\end{array}$ & $\begin{array}{c}0.3790 * * * \\
(9.2665)\end{array}$ & $\begin{array}{c}0.0015 \\
(0.7990)\end{array}$ & $\begin{array}{c}0.0149 \\
(1.5785)\end{array}$ \\
\hline Surprise Both Top Two & $\begin{array}{c}0.7307 * * * \\
(8.3590)\end{array}$ & & $\begin{array}{c}0.7206^{* * *} \\
(11.9490)\end{array}$ & & $\begin{array}{c}0.7141 * * * \\
(12.2602)\end{array}$ & & \\
\hline Surprise Both Bottom Two & $\begin{array}{c}0.6436 * * * \\
(7.1122)\end{array}$ & & $\begin{array}{c}0.7743 * * * \\
(12.5876)\end{array}$ & & $\begin{array}{c}0.7854 * * * \\
(13.2316)\end{array}$ & & \\
\hline Observations & 3,365 & 3,365 & 6,474 & 6,474 & 6,845 & 6,845 & 6,845 \\
\hline Link Industry FE & Yes & Yes & Yes & Yes & Yes & Yes & Yes \\
\hline Year+Month+Day FE & Yes & Yes & Yes & Yes & Yes & Yes & Yes \\
\hline
\end{tabular}




\section{Table 11. Parent's Subsidizing Behavior}

The table investigates possible effects of internal capital markets. The table presents results from regressions of parent company investor reactions to subsidiary's earnings announcement, for the case where parent and subsidiary close their financial year on the same date and where the parent releases earnings first. Parent Neg. Earnings is equal to one if the parent announces negative earnings, and zero otherwise. $Q$ is the subsidiary's market-to-book ratio. $d Q$ is the difference between subsidiary's and parent's market-to-book ratios. $i Q$ is a dummy variable that takes the value one if $d Q$ is strictly positive. Also included are company controls, year, month, day-of-the-week fixed effects, parent controls (parent's market value, log of analyst coverage, and an illiquidity variable), and link control variables (relative market value, percentage of control held by parent, percentage of common analysts, a direct ownership dummy, dummy variables equal to one if parent and subsidiary are located in the same country, if they share part of a corporate name, and if they share a common institutional investors, respectively. Robust t-stats are reported between brackets. *, **, and $* * *$ indicate significance at the $10 \%, 5 \%$, and $1 \%$ level, respectively.

\begin{tabular}{|c|c|c|c|c|c|}
\hline \multirow{2}{*}{ Time window } & \multicolumn{5}{|c|}{ Parent Investor Reactions to Subsidiary's Announcement } \\
\hline & (1) & (2) & (3) & (4) & (5) \\
\hline \multirow[t]{2}{*}{ S' Top Two Quantiles } & $0.0039 * *$ & 0.0021 & 0.0015 & 0.0015 & -0.0034 \\
\hline & $(2.1168)$ & $(1.2317)$ & $(0.6037)$ & $(0.7946)$ & $(-1.2951)$ \\
\hline \multirow[t]{2}{*}{ P' Negative Earnings } & -0.0006 & -0.0033 & -0.0027 & -0.0036 & $-0.0069 * *$ \\
\hline & $(-0.2173)$ & $(-1.0990)$ & $(-0.7714)$ & $(-1.1880)$ & $(-1.9977)$ \\
\hline \multirow[t]{2}{*}{ S' Top Two x P' Neg. Earnings } & & $0.0106^{* *}$ & $0.0146^{* *}$ & $0.0115^{* *}$ & $0.0224 * * *$ \\
\hline & & $(2.0139)$ & $(2.2300)$ & $(2.1468)$ & $(2.9279)$ \\
\hline \multirow[t]{2}{*}{ Q (subsidiary) } & & & $0.0035^{*}$ & & \\
\hline & & & $(1.8327)$ & & \\
\hline \multirow[t]{2}{*}{ S' Top Two x Q } & & & 0.0015 & & \\
\hline & & & $(0.8076)$ & & \\
\hline \multirow[t]{2}{*}{ P' Negative Earnings x Q } & & & -0.0008 & & \\
\hline & & & $(-0.3648)$ & & \\
\hline \multirow[t]{2}{*}{ S' Top Two x P' Neg. Earnings x Q } & & & $-0.0062 * *$ & & \\
\hline & & & $(-2.0004)$ & & \\
\hline \multirow[t]{2}{*}{$d Q=S^{\prime} Q-P^{\prime} Q$} & & & & $-0.0026^{*}$ & \\
\hline & & & & $(-1.8469)$ & \\
\hline \multirow[t]{2}{*}{ S' Top Two x dQ } & & & & $0.0062 * * *$ & \\
\hline & & & & $(3.8849)$ & \\
\hline \multirow[t]{2}{*}{$P^{\prime}$ Neg. Earnings $x$ dQ } & & & & $0.0038 * *$ & \\
\hline & & & & $(2.1961)$ & \\
\hline \multirow[t]{2}{*}{ S' Top Two x P'Neg. Earnings x dQ } & & & & $-0.0096 * * *$ & \\
\hline & & & & $(-3.7271)$ & \\
\hline \multirow[t]{2}{*}{$\mathrm{iQ}=\mathrm{i}\left(\mathrm{S}^{\prime} \mathrm{Q}>\mathrm{P}^{\prime} \mathrm{Q}\right)$} & & & & & $-0.0061 * *$ \\
\hline & & & & & $(-2.1380)$ \\
\hline \multirow[t]{2}{*}{ S' Top Two x iQ } & & & & & $0.0100 * * *$ \\
\hline & & & & & (3.1577) \\
\hline \multirow[t]{2}{*}{$\mathrm{P}^{\prime}$ Negative Earnings $\mathrm{x}$ iQ } & & & & & 0.0069 \\
\hline & & & & & (1.3644) \\
\hline \multirow[t]{2}{*}{ S' Top Two x P'Neg. Earnings x iQ } & & & & & $-0.0236 * *$ \\
\hline & & & & & $(-2.2942)$ \\
\hline Observations & 1,969 & 1,969 & 1,966 & 1,966 & 1,969 \\
\hline R-squared & 0.0298 & 0.0327 & 0.0392 & 0.0375 & 0.0385 \\
\hline Link Controls & Yes & Yes & Yes & Yes & Yes \\
\hline Link Industry FE & Yes & Yes & Yes & Yes & Yes \\
\hline Year+Month+Day FE & Yes & Yes & Yes & Yes & Yes \\
\hline
\end{tabular}




\section{Table 12. Confounding Events: Parent Investor Reaction to Subsidiary's Announcements}

The table presents results from regressions of parent investor reactions to the subsidiary's earnings announcements of earnings surprises (belonging to the top two quantiles of their distribution) for the case where the subsidiary releases its earnings information first. Observations with parent and subsidiary closing their financial year at different dates are also included in this sample. Columns (1) reports parent's investors delayed reaction to the subsidiary's announcement over $[+2 ;+60]$ trading days after the announcement. A contaminated window variable is included and takes the value one if the parent announces within a period of 60 trading days after the subsidiary's announcement (over which the delayed reaction is calculated). Columns (2-5) report delayed parent investor reactions to the subsidiary's announcement, calculated for different event windows prior to the parent's announcement - observations with parent's announcements occurring within the event window are here excluded. All specifications include a dummy variable same financial year that is equal to one if parent and subsidiary close their financial year on the same date. The specifications include parent controls (market value, log of analyst coverage, Tobin's Q, and an illiquidity variable), time-varying link controls (relative market value, percentage of common analysts, and a dummy common institutional outside investor), link (parent-subsidiary) fixed effects and time (year, month, day-of-the-week) fixed effects. Robust t-stats are reported between brackets. $*, * *$, and $* * *$ indicate significance at the $10 \%, 5 \%$, and $1 \%$ level, respectively.

\begin{tabular}{lccccc}
\hline & $(1)$ & $(2)$ & $(3)$ & $(4)$ & $(5)$ \\
Time window & BHAR[2;60] & BHAR[2;10] & BHAR[2;20] & BHAR[2;30] & BHAR[2;40] \\
\hline \multirow{2}{*}{ Top Two Quantiles } & & & & & \\
& $0.0243^{* * *}$ & $0.0104^{* *}$ & $0.0173^{*}$ & $0.0308^{* *}$ & $0.0309^{*}$ \\
& $(2.8645)$ & $(2.2521)$ & $(1.8830)$ & $(2.1582)$ & $(1.8625)$ \\
Contaminated Window & 0.0026 & & & & \\
& $(0.2287)$ & & & & \\
Same Fiscal Year & 0.1429 & $0.0431^{* * *}$ & 0.0514 & 0.0018 & -0.0384 \\
& $(1.2292)$ & $(3.5009)$ & $(1.1068)$ & $(0.0417)$ & $(-0.3718)$ \\
& & & & & \\
Observations & 2,757 & 1,162 & 774 & 575 & 496 \\
R-squared & 0.1553 & 0.0837 & 0.0904 & 0.1542 & 0.2002 \\
Number of pairid & 1,117 & 549 & 369 & 261 & 215 \\
Firm Controls & Yes & Yes & Yes & Yes & Yes \\
Link Controls & Yes & Yes & Yes & Yes & Yes \\
Link FE & Yes & Yes & Yes & Yes & Yes \\
Year+Month+Day FE & Yes & Yes & Yes & Yes & Yes \\
\hline
\end{tabular}




\section{Table 13. Main Models with Country Fixed Effects}

The table presents results on investor reactions to earnings announcement of earnings surprises (belonging to the top two quantiles of their distribution), for the cases where parent and subsidiary close their financial year on the same date. Panel A reports report investors' reactions when the parent announces first. Panel B reports report investors' reactions when the subsidiary announces first. All specifications report results with year, month, day-of-the-week fixed-effects, link (parent-subsidiary) country fixed effects, parent controls, and link controls. Parent controls comprise the parent's market value, log of analyst coverage, the Tobin's Q, and an illiquidity dummy. Link controls include relative market value, percentage of control held by the parent, percentage of common analysts, a directly ownership dummy, dummy variables equal to one if parent and subsidiary operates in the same SIC-2 industry, share (part of) a corporate name, and if they share a common institutional investor respectively. Robust t-stats are reported between brackets. *,**, and *** indicate significance at the $10 \%, 5 \%$, and $1 \%$ level, respectively.

Panel A: Parent Announces First

\begin{tabular}{|c|c|c|c|c|c|c|c|c|}
\hline \multirow{4}{*}{ Time window } & \multicolumn{4}{|c|}{ Parent's Investors } & \multicolumn{4}{|c|}{ Subsidiary's Investors } \\
\hline & \multicolumn{2}{|c|}{$\mathrm{P}^{\prime}$ Announcement } & \multicolumn{2}{|c|}{ S' Announcement } & \multicolumn{2}{|c|}{ P' Announcement } & \multicolumn{2}{|c|}{ S' Announcement } \\
\hline & {$[0 ; 1]$} & {$[2 ; 60]$} & {$[0 ; 1]$} & {$[2 ; 60]$} & {$[0 ; 1]$} & {$[2 ; 60]$} & {$[0 ; 1]$} & {$[2 ; 60]$} \\
\hline & (1) & (2) & (3) & (4) & (5) & (6) & (7) & (8) \\
\hline \multirow{2}{*}{ Top Two Quantiles } & $0.0117 * *$ & -0.0099 & $0.0023 *$ & -0.0075 & 0.0000 & 0.0001 & $0.0144 * *$ & $0.0184 *$ \\
\hline & $(2.1137)$ & $(-1.4972)$ & (1.7477) & $(-1.3329)$ & $(0.0056)$ & $(0.0114)$ & (2.5099) & $(1.8752)$ \\
\hline Observations & 926 & 926 & 2,370 & 2,370 & 1,669 & 1,669 & 1,878 & 1,878 \\
\hline R-squared & 0.0646 & 0.1561 & 0.0219 & 0.1080 & 0.0534 & 0.1766 & 0.0428 & 0.1451 \\
\hline Firm Controls & Yes & Yes & Yes & Yes & Yes & Yes & Yes & Yes \\
\hline Firm Country FE & Yes & Yes & No & No & No & No & Yes & Yes \\
\hline Link Controls & No & No & Yes & Yes & Yes & Yes & No & No \\
\hline Link Country FE & No & No & Yes & Yes & Yes & Yes & No & No \\
\hline Year+Month+Day FE & Yes & Yes & Yes & Yes & Yes & Yes & Yes & Yes \\
\hline
\end{tabular}

Panel B: Subsidiary Announces First

\begin{tabular}{|c|c|c|c|c|c|c|c|c|}
\hline \multirow[b]{3}{*}{ Time window } & \multicolumn{4}{|c|}{ Parent's Investors } & \multicolumn{4}{|c|}{ Subsidiary's Investors } \\
\hline & \multicolumn{2}{|c|}{ S' Announcement } & \multicolumn{2}{|c|}{$\mathrm{P}^{\prime}$ Announcement } & \multicolumn{2}{|c|}{$S^{\prime}$ Announcement } & \multicolumn{2}{|c|}{$\mathrm{P}^{\prime}$ Announcement } \\
\hline & {$[0 ; 1]$} & {$[2 ; 60]$} & {$[0 ; 1]$} & {$[2 ; 60]$} & {$[0 ; 1]$} & {$[2 ; 60]$} & {$[0 ; 1]$} & {$[2 ; 60]$} \\
\hline Top Two Quantiles & $\begin{array}{l}0.0033^{*} \\
(1.8012)\end{array}$ & $\begin{array}{c}0.0332 * * * \\
(3.8888)\end{array}$ & $\begin{array}{c}0.0126 * * * \\
(4.5823)\end{array}$ & $\begin{array}{c}0.0156 \\
(1.6321)\end{array}$ & $\begin{array}{c}0.0199 * * * \\
(5.8042)\end{array}$ & $\begin{array}{c}0.0291 * * * \\
(3.3393)\end{array}$ & $\begin{array}{c}0.0000 \\
(0.0018)\end{array}$ & $\begin{array}{c}0.0144 * * \\
(2.0553)\end{array}$ \\
\hline Observations & 2,229 & 2,229 & 1,236 & 1,236 & 2,125 & 2,125 & 2,541 & 2,541 \\
\hline $\mathrm{R}$-squared & 0.0376 & 0.1645 & 0.0430 & 0.1822 & 0.0531 & 0.1470 & 0.0200 & 0.1477 \\
\hline Firm Controls & Yes & Yes & Yes & Yes & Yes & Yes & Yes & Yes \\
\hline Firm Country FE & No & No & Yes & Yes & Yes & Yes & No & No \\
\hline Link Controls & Yes & Yes & No & No & No & No & Yes & Yes \\
\hline Link Country FE & Yes & Yes & No & No & No & No & Yes & Yes \\
\hline Year+Month+Day FE & Yes & Yes & Yes & Yes & Yes & Yes & Yes & Yes \\
\hline
\end{tabular}

